\title{
Modeling the Dynamics of Continental Shelf Carbon
}

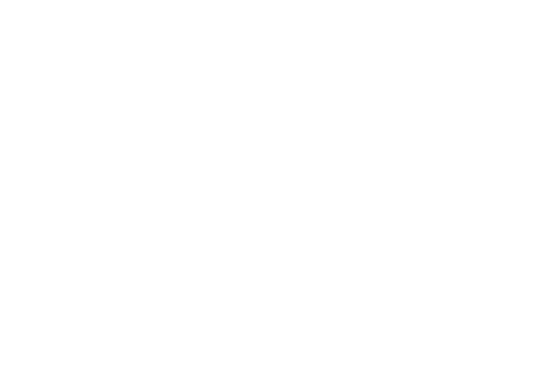

Annu. Rev. Mar. Sci. 2011. 3:93-122

First published online as a Review in Advance on November 12, 2010

The Annual Review of Marine Science is online at marine.annualreviews.org

This article's doi:

10.1146/annurev-marine-120709-142740

Copyright (c) 2011 by Annual Reviews. All rights reserved

$1941-1405 / 11 / 0115-0093 \$ 20.00$

\section{Eileen E. Hofmann, ${ }^{1}$ Bronwyn Cahill, ${ }^{2}$ Katja Fennel, ${ }^{3}$ Marjorie A.M. Friedrichs, ${ }^{4}$ Kimberly Hyde, ${ }^{5}$ Cindy Lee, ${ }^{6}$ Antonio Mannino, ${ }^{7}$ Raymond G. Najjar, ${ }^{8}$ John E. O’Reilly, John Wilkin, ${ }^{2}$ and Jianhong Xue ${ }^{4,9}$}

${ }^{1}$ Center for Coastal Physical Oceanography, Old Dominion University, Norfolk, Virginia 23508; email: hofmann@ccpo.odu.edu

${ }^{2}$ Institute of Marine and Coastal Sciences, Rutgers University, New Brunswick, New Jersey 08901-8521; email: bronwyn@marine.rutgers.edu, wilkin@marine.rutgers.edu ${ }^{3}$ Department of Oceanography, Dalhousie University, Halifax, Nova Scotia B3H4J1, Canada; email: katja.fennel@dal.ca

${ }^{4}$ Virginia Institute of Marine Science, College of William \& Mary, Gloucester Point, Virginia 23062; email: marjy@vims.edu

${ }^{5}$ NOAA/NMFS Narragansett Laboratory, Narragansett, Rhode Island 02882; email: jay.oreilly@noaa.gov, kimberly.hyde@noaa.gov

${ }^{6}$ Marine Sciences Research Center, Stony Brook University, Stony Brook, New York 11794-5000; email: cindy.lee@sunysb.edu

${ }^{7}$ NASA Goddard Space Flight Center, Greenbelt, Maryland 20771; email: antonio.mannino@nasa.gov

${ }^{8}$ Department of Meteorology, The Pennsylvania State University, University Park, Pennsylvania 16802; email: najjar@meteo.psu.edu

${ }^{9}$ Marine Science Institute, The University of Texas at Austin, Port Aransas, Texas 78373; email: jxue@mail.utexas.edu

\section{Keywords}

carbon cycling, continental shelf, coupled circulation-biogeochemical models, model-data comparisons, data assimilation, biogeochemical model initialization

\begin{abstract}
Continental margin systems are important contributors to global nutrient and carbon budgets. Effort is needed to quantify this contribution and how it will be modified under changing patterns of climate and land use. Coupled models will be used to provide projections of future states of continental margin systems. Thus, it is appropriate to consider the limitations that impede the development of realistic models. Here, we provide an overview of the current state of modeling carbon cycling on continental margins as well as the processes and issues that provide the next challenges to such models. Our overview is done within the context of a coupled circulation-biogeochemical model developed for the northeastern North American continental shelf region. Particular choices of forcing and initial fields and process parameterizations are used to illustrate the consequences for simulated distributions, as revealed by comparisons to observations using quantitative statistical metrics.
\end{abstract}




\section{INTRODUCTION}

Continental margin systems make up only approximately $8 \%$ of the world oceans but contribute an estimated 19-28\% of total global primary production (Longhurst 1995). These productive regions (Figure 1) support a variety of marine ecosystems that are characterized by food webs and biogeochemical cycling with varying levels of connectivity and linkages (see Liu et al. 2010 for a review). The carbon and nutrient fluxes and dynamics resulting from these internal food web and biogeochemical transformations are diverse and are further modified by sediment-water interactions, air-sea fluxes, and land-ocean inputs that affect all continental margin systems. These systems have been recognized as being potentially important contributors to global nutrient and carbon budgets (e.g., Walsh et al. 1981, Muller-Karger et al. 2005, Seitzinger et al. 2006). However, the limited number of multidisciplinary studies conducted in only a few of these diverse systems has not allowed reliable quantitative estimates of the overall importance of continental margin systems to these global budgets.

An example of the diversity of opinions concerning the role of continental margin systems in global carbon budgets is the ongoing debate about the importance of these systems as sinks for atmospheric carbon dioxide $\left(\mathrm{CO}_{2}\right.$; e.g., Tsunogai et al. 1999, Frankignoulle \& Borges 2001, DeGrandpre et al. 2002, Thomas et al. 2004). Recent compilations of observational estimates document that variability in coastal air-sea $\mathrm{CO}_{2}$ fluxes is large but suggest that mid- and highlatitude systems generally act as sinks of atmospheric $\mathrm{CO}_{2}$, whereas subtropical and tropical regions generally act as sources (Cai et al. 2006, 2011; Borges et al. 2005). In addition, two recent attempts to budget continental shelf $\mathrm{CO}_{2}$ uptake (Borges et al. 2005, Cai et al. 2006) arrived at different global estimates of uptake ( $0.45 \mathrm{Pg} \mathrm{C} \mathrm{y}^{-1}$ versus $0.22 \mathrm{Pg} \mathrm{C} \mathrm{y}^{-1}$, respectively), which illustrates

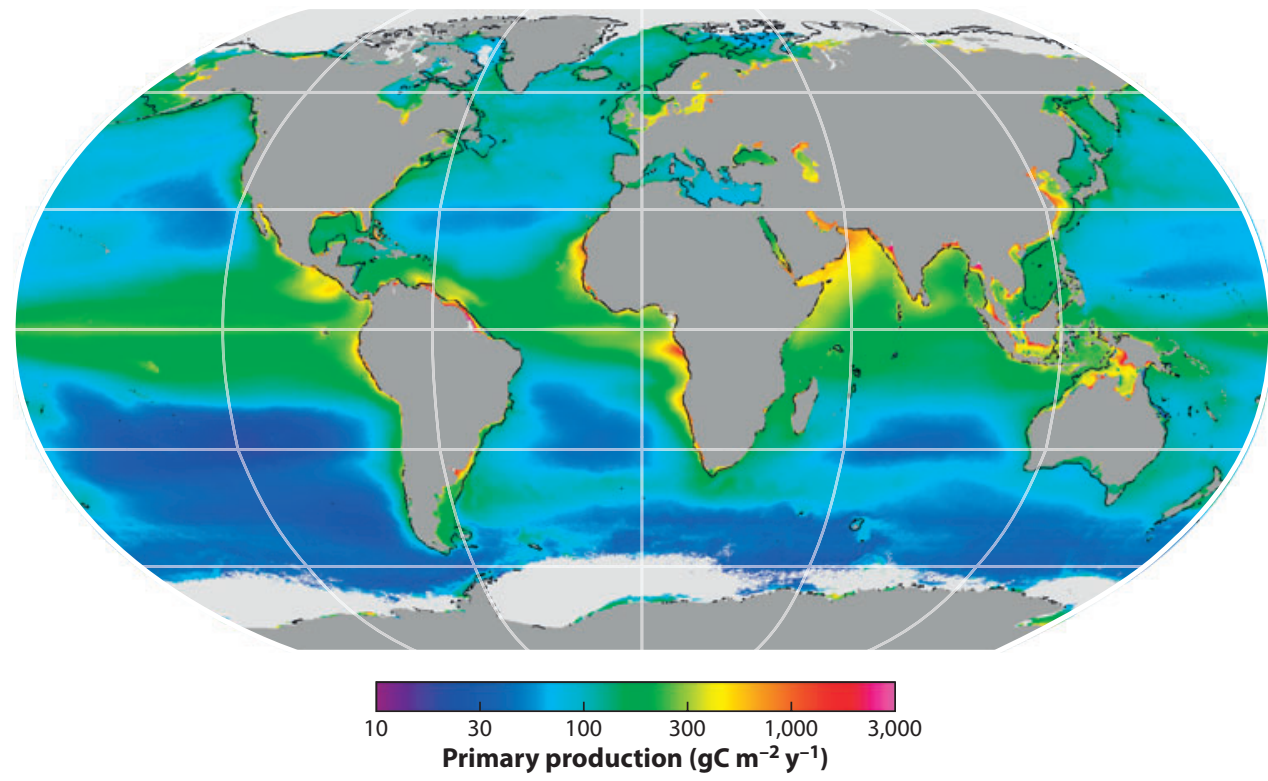

Figure 1

Annual mean global primary production distribution estimated from ocean color measurements obtained from the Sea-viewing Wide Field-of-view Sensor (SeaWiFS) using the Ocean Productivity from Absorption of Light (OPAL) model (Marra et al. 2007). The 200-m isobath (thin black line) denotes the continental shelf edge. 
Table 1 Selection of food web-mass balance models constructed for an annual time scale

\begin{tabular}{|c|c|c|c|c|c|}
\hline Study region & $\begin{array}{l}\text { Carbon burial } \\
\text { and/or export } \\
\left(\mathrm{g} \mathrm{C} \mathrm{m}^{-2} \mathrm{y}^{-1}\right)\end{array}$ & $\begin{array}{c}\text { Carbon yield to } \\
\text { benthos } \\
\left(\mathrm{g} \mathrm{C} \mathrm{m}^{-2} \mathrm{y}^{-1}\right) \\
\end{array}$ & $\begin{array}{l}\text { Carbon yield to } \\
\text { top predators } \\
\left(\mathrm{g} \mathrm{C} \mathrm{m}^{-2} \mathrm{y}^{-1}\right) \\
\end{array}$ & $\begin{array}{c}\text { Carbon yield to } \\
\text { humans } \\
\left(\mathrm{g} \mathrm{C} \mathrm{m}^{-2} \mathrm{y}^{-1}\right) \\
\end{array}$ & Reference \\
\hline $\begin{array}{l}\text { Texas-Louisiana } \\
\text { continental shelf }\end{array}$ & 56 & $\mathrm{NC}^{\mathrm{a}}$ & 0.35 & 0.34 & Walsh et al. 1981 \\
\hline New York continental shelf & 180 & 245.2 & 2.7 & 0.63 & Walsh et al. 1981 \\
\hline Peru continental shelf & $82-591$ & $25-116.5$ & $67.1-600.5$ & $6.7-60.05$ & Walsh et al. 1981 \\
\hline $\begin{array}{l}\text { Florida-Georgia } \\
\text { continental shelf }\end{array}$ & $\mathrm{NC}$ & 90 & 3.2 & 0.5 & Pace et al. 1984 \\
\hline $\begin{array}{l}\text { Southeastern Bering Sea } \\
\text { outer shelf }\end{array}$ & $28-79$ & $43-162$ & $8.3-29.2$ & $0.64-0.67$ & $\begin{array}{l}\text { Walsh \& McRoy } \\
1986\end{array}$ \\
\hline
\end{tabular}

${ }^{a} \mathrm{NC}$, quantity not calculated.

the large uncertainty in extrapolations from local to global estimates. Even within the same shelf system, there is debate as to whether there is a source or sink of atmospheric $\mathrm{CO}_{2}$. Cai et al. (2003) and Wang et al. (2005) concluded that the U.S. South Atlantic Bight (SAB) operates as a source of $\mathrm{CO}_{2}$ to the atmosphere. This is in contrast to a more recent study (Jiang et al. 2008), which found that although the inner shelf acts as a net source of $\mathrm{CO}_{2}$ to the atmosphere, the midand outer shelf regions, as well as the $\mathrm{SAB}$ as a whole, are a net $\mathrm{CO}_{2}$ sink on an annual basis. The debate over the source/sink status of continental margin systems is critically important given the potentially large magnitude of $\mathrm{CO}_{2}$ fluxes in these systems relative to the total $\mathrm{CO}_{2}$ uptake by the world ocean (at present, approximately $2 \mathrm{Pg} \mathrm{C} \mathrm{y}^{-1}$ ).

The divergent results described above arise largely from the difficulty in extrapolating from data collected on individual cruises, conducted with limited spatial and temporal coverage, to fluxes representative of an entire continental shelf that allow for the large spatial and temporal variability inherent in these systems. Coupled-modeling frameworks provide an approach for extending beyond the confines of limited measurements to quantify carbon and nutrient fluxes in continental margins (reviewed in Moisan 2010) (Tables 1 and 2). These models allow selfconsistent estimates of nutrient and carbon fluxes and thus provide a common basis for making comparisons between model-based carbon estimates from different regions.

Models integrate theoretical knowledge and laboratory measurements and complement fieldbased approaches. At the most basic level, all models routinely require mass to be conserved, and three-dimensional (3D) circulation models generally have the additional constraints of momentum and energy conservation. As models become more complex, knowledge from experimental studies, such as relationships between light and primary production, and from field studies, with measured concentrations and rates, are used to place further constraints. Ideally, a blending of approaches based on models, theory, and observations (satellite, field and laboratory) are used to address issues in environmental science, including the carbon cycle of continental shelves.

Models are useful tools for evaluating hypotheses and climate effects, past and present. For example, Previdi et al. (2009) analyzed the sensitivity of air-sea $\mathrm{CO}_{2}$ fluxes to atmospheric forcing by contrasting simulations of a model for the U.S. eastern continental shelf for opposite phases of the North Atlantic Oscillation (the dominant mode of atmospheric variability in the North Atlantic). In this case, it was possible to quantify the relative importance of different factors (e.g., changes in primary production, wind forcing) to changes in the air-sea flux of $\mathrm{CO}_{2}$. Climate change and variability have already affected coastal systems (Cook et al. 1998, Hagy et al. 2004, Diaz \& 
Table 2 Selection of coupled circulation-lower trophic level models developed for continental shelf systems that provide estimates of annual primary production, air-sea $\mathrm{CO}_{2}$ flux, and sediment denitrification

\begin{tabular}{|c|c|c|c|c|c|}
\hline $\begin{array}{l}\text { Study } \\
\text { region }\end{array}$ & Model type & $\begin{array}{l}\text { Primary carbon } \\
\text { and flux controls }\end{array}$ & $\begin{array}{c}\text { Model } \\
\text { application }\end{array}$ & Simulation diagnostic & Reference \\
\hline $\begin{array}{l}\text { Central } \\
\text { North Sea }\end{array}$ & $\begin{array}{l}\text { 1D, mixed- layer, } \\
\text { with observed } \\
\text { meteorological } \\
\text { forcing, lower } \\
\text { trophic levels }\end{array}$ & $\begin{array}{l}\text { Atmospheric } \\
\text { forcing, } \\
\text { zooplankton } \\
\text { grazing }\end{array}$ & $\begin{array}{l}\text { Annual cycles of } \\
\text { environment and } \\
\text { phytoplankton }\end{array}$ & PP: $43-64 \mathrm{~g} \mathrm{C} \mathrm{m}^{-2} \mathrm{y}^{-1}$ & $\begin{array}{l}\text { Radach \& Moll } \\
1993\end{array}$ \\
\hline $\begin{array}{l}\text { Bering- } \\
\text { Chukchi } \\
\text { seas }\end{array}$ & $\begin{array}{l}\text { 3D, barotrophic } \\
\text { circulation, lower } \\
\text { trophic levels }\end{array}$ & $\begin{array}{l}\text { Advection, benthic } \\
\text { respiration and } \\
\text { regeneration }\end{array}$ & $\begin{array}{l}\text { Fate and export of } \\
\text { carbon }\end{array}$ & PP: $360 \mathrm{~g} \mathrm{C} \mathrm{m}^{-2} \mathrm{y}^{-1}$ & $\begin{array}{l}\text { Shuert \& Walsh } \\
1993\end{array}$ \\
\hline $\begin{array}{l}\text { Southeastern } \\
\text { Bering Sea }\end{array}$ & $\begin{array}{l}\text { 2D, mixed-layer, } \\
\text { complex } \\
\text { biogeochemical } \\
\text { processes }\end{array}$ & $\begin{array}{l}\text { Vertical mixing, } \\
\text { benthic processes, } \\
\text { internal } \\
\text { biological } \\
\text { transformations }\end{array}$ & $\begin{array}{l}\text { Seasonal cycles, } \\
\text { annual } \\
\text { distributions }\end{array}$ & $\begin{array}{l}\text { PP: } 140 \mathrm{~g} \mathrm{C} \mathrm{m}^{-2} \mathrm{y}^{-1} \\
\text { ASF: } 30 \mathrm{~g} \mathrm{C} \mathrm{m}^{-2} \mathrm{y}^{-1}\end{array}$ & $\begin{array}{l}\text { Walsh \& } \\
\text { Dieterle } 1994\end{array}$ \\
\hline North Sea & $\begin{array}{l}\text { 3D, coupled } \\
\text { circulation, } \\
\text { nutrient, } \\
\text { phytoplankton }\end{array}$ & $\begin{array}{l}\text { River inputs, } \\
\text { radiation, internal } \\
\text { biological } \\
\text { transformations }\end{array}$ & $\begin{array}{l}\text { Annual primary } \\
\text { production and } \\
\text { regional } \\
\text { variability }\end{array}$ & PP: $145 \mathrm{~g} \mathrm{C} \mathrm{m}^{-2} \mathrm{y}^{-1}$ & Moll 1998 \\
\hline $\begin{array}{l}\text { Northwest } \\
\text { European } \\
\text { continental } \\
\text { shelf }\end{array}$ & $\begin{array}{l}\text { 3D, coupled } \\
\text { circulation, lower } \\
\text { trophic levels, } \\
\text { benthic suspended } \\
\text { sediment }\end{array}$ & $\begin{array}{l}\text { Circulation, } \\
\text { radiance }\end{array}$ & $\begin{array}{l}\text { Seasonal nutrient } \\
\text { and } \\
\text { phytoplankton } \\
\text { cycles }\end{array}$ & $\begin{array}{l}\text { Nutrient and } \\
\text { phytoplankton patterns }\end{array}$ & Allen et al. 2001 \\
\hline $\begin{array}{l}\text { West coast } \\
\text { Vancouver } \\
\text { Island, } \\
\text { British } \\
\text { Columbia }\end{array}$ & $\begin{array}{l}\text { 2D, upwelling } \\
\text { circulation, POC, } \\
\text { DIC, DOC }\end{array}$ & $\begin{array}{l}\text { Light, relative } \\
\text { strength of } \\
\text { upwelling to } \\
\text { downwelling } \\
\text { circulation }\end{array}$ & $\begin{array}{l}\text { Annual primary } \\
\text { production, } \\
\text { air-sea flux, } \\
\text { export flux of } \\
\text { DOC and import } \\
\text { flux of DIC }\end{array}$ & $\begin{array}{l}\text { PP: } 410 \mathrm{~g} \mathrm{C} \mathrm{m}^{-2} \mathrm{y}^{-1} \\
\text { ASF: } 6 \mathrm{~g} \mathrm{C} \mathrm{m}^{-2} \mathrm{y}^{-1}\end{array}$ & $\begin{array}{l}\text { Ianson \& Allen } \\
2002\end{array}$ \\
\hline $\begin{array}{l}\text { California } \\
\text { Current } \\
\text { System }\end{array}$ & $\begin{array}{l}\text { 3D, coupled } \\
\text { circulation, lower } \\
\text { trophic levels }\end{array}$ & $\begin{array}{l}\text { Advection, internal } \\
\text { biological } \\
\text { transformations }\end{array}$ & $\begin{array}{l}\text { Seasonal cycles, } \\
\text { annual } \\
\text { distributions }\end{array}$ & $\begin{array}{l}\text { PP: } 27,002 \times 10^{3} \mathrm{t} \mathrm{C} \mathrm{y}^{-1} \\
\text { ASF: } 733 \times 10^{3} \mathrm{t} \mathrm{C} \mathrm{y}^{-1}\end{array}$ & $\begin{array}{l}\text { Gruber et al. } \\
2006 \text { (as } \\
\text { recalculated and } \\
\text { given in Moisan } \\
2010 \text { ) } \\
\end{array}$ \\
\hline $\begin{array}{l}\text { Middle } \\
\text { Atlantic } \\
\text { Bight } \\
\text { NENA } \\
\text { model }\end{array}$ & $\begin{array}{l}\text { 3D, coupled } \\
\text { circulation, } \\
\text { nutrient, lower } \\
\text { trophic levels, } \\
\text { benthic } \\
\text { component }\end{array}$ & $\begin{array}{l}\text { River inputs, } \\
\text { radiation, ocean } \\
\text { inputs, air-sea } \\
\text { fluxes, internal } \\
\text { biological } \\
\text { transformations }\end{array}$ & $\begin{array}{l}\text { Annual mid-shelf } \\
\text { air-sea flux }\end{array}$ & $\begin{array}{l}\text { PP: } 245 \mathrm{~g} \mathrm{C} \mathrm{m}^{-2} \mathrm{y}^{-1} \\
\text { ASF: } 14.2 \mathrm{~g} \mathrm{C} \mathrm{m}^{-2} \mathrm{y}^{-1} \\
\text { SDN: } 0.33 \mathrm{~mol} \mathrm{~N} \mathrm{~m}^{-2} \mathrm{y}^{-1}\end{array}$ & Fennel et al. 2008 \\
\hline $\begin{array}{l}\text { Ross Sea } \\
\text { continental } \\
\text { shelf }\end{array}$ & $\begin{array}{l}\text { 3D, coupled } \\
\text { circulation, } \\
\text { nutrient, lower } \\
\text { trophic levels }\end{array}$ & $\begin{array}{l}\text { Radiation, air-sea } \\
\text { fluxes, sea ice } \\
\text { cover, wind, } \\
\text { internal } \\
\text { biological } \\
\text { transformations }\end{array}$ & $\begin{array}{l}\text { Annual primary } \\
\text { production, } \\
\text { air-sea flux, } \\
\text { sinking }\end{array}$ & $\begin{array}{l}\text { NPP: } 0.055 \mathrm{Pg} \mathrm{C} \mathrm{y}^{-1} \\
\text { ASF: } 20-50 \mathrm{~g} \mathrm{C} \mathrm{m}^{-2} \mathrm{y}^{-1}\end{array}$ & Arrigo et al. 2008 \\
\hline
\end{tabular}




\begin{tabular}{|c|c|c|c|c|c|}
\hline Study region & Model type & $\begin{array}{l}\text { Primary carbon } \\
\text { and flux controls }\end{array}$ & $\begin{array}{c}\text { Model } \\
\text { application }\end{array}$ & Simulation diagnostic & Reference \\
\hline $\begin{array}{l}\text { South China } \\
\text { Sea }\end{array}$ & $\begin{array}{l}\text { 3D, coupled } \\
\text { circulation, lower } \\
\text { trophic levels }\end{array}$ & $\begin{array}{l}\text { Air-sea fluxes, } \\
\text { internal biological } \\
\text { transformations }\end{array}$ & $\begin{array}{l}\text { Seasonal and } \\
\text { interannual } \\
\text { variability in } \\
\text { primary } \\
\text { production }\end{array}$ & PP: $72 \mathrm{~g} \mathrm{C} \mathrm{m}^{-2} \mathrm{y}^{-1}$ & Liu \& Chai 2009 \\
\hline $\begin{array}{l}\text { South China } \\
\text { Sea }\end{array}$ & $\begin{array}{l}\text { 3D, coupled } \\
\text { circulation, lower } \\
\text { trophic levels }\end{array}$ & $\begin{array}{l}\text { SST, } \mathrm{TCO}_{2}, \\
\text { biological } \\
\text { transformations }\end{array}$ & $\begin{array}{l}\text { Seasonal and } \\
\text { annual sea-air } \\
\mathrm{CO}_{2} \text { flux }\end{array}$ & ASF: $4 \mathrm{~g} \mathrm{CO}_{2} \mathrm{~m}^{-2} \mathrm{y}^{-1}$ & Chai et al. 2009 \\
\hline $\begin{array}{l}\text { Middle } \\
\text { Atlantic } \\
\text { Bight } \\
\text { NENA } \\
\text { model }\end{array}$ & $\begin{array}{l}\text { 3D, coupled } \\
\text { circulation, } \\
\text { nutrient, carbon, } \\
\text { lower trophic } \\
\text { levels }\end{array}$ & $\begin{array}{l}\text { River inputs, } \\
\text { radiation, ocean } \\
\text { inputs, air-sea } \\
\text { fluxes, internal } \\
\text { biological } \\
\text { transformations }\end{array}$ & $\begin{array}{l}\text { Annual carbon } \\
\text { export from shelf }\end{array}$ & $\begin{array}{l}50 \times 10^{6} \mathrm{~mol} \mathrm{C} \mathrm{y}^{-1} \text { per } \\
\text { kilometer of along-shelf } \\
\text { distance }\end{array}$ & $\begin{array}{l}\text { Fennel \& Wilkin } \\
2009\end{array}$ \\
\hline $\begin{array}{l}\text { Middle } \\
\text { Atlantic } \\
\text { Bight } \\
\text { NENA } \\
\text { model }\end{array}$ & $\begin{array}{l}\text { 3D, coupled } \\
\text { circulation, } \\
\text { nutrient, lower } \\
\text { trophic levels, } \\
\text { benthic } \\
\text { component, } \\
\text { DOM }\end{array}$ & $\begin{array}{l}\text { River inputs, } \\
\text { radiation, ocean } \\
\text { inputs, air-sea } \\
\text { fluxes, internal } \\
\text { biological } \\
\text { transformations, } \\
\text { DOM cycling }\end{array}$ & $\begin{array}{l}\text { Seasonal and } \\
\text { annual DOC } \\
\text { export from from } \\
\text { shelf }\end{array}$ & $1-2 \mathrm{~mol} \mathrm{C} \mathrm{m}^{-2} \mathrm{y}^{-1}$ & Druon et al. 2010 \\
\hline
\end{tabular}

Abbreviations: ASF, air-sea $\mathrm{CO}_{2}$ flux; DIC, dissolved inorganic carbon; DOC, dissolved organic carbon; DOM, dissolved organic matter; NENA, northeastern North American; NPP, net primary production; POC, particulate organic carbon; PP, annual primary production; SDN, sediment denitrification; SST, sea surface temperature.

Rosenberg 2008, Najjar et al. 2010), and thus it is likely that future human-induced changes in greenhouse gases, with their associated impacts on temperature, sea level, streamflow, acidity, and ocean circulation, will have dramatic impacts on coastal systems. As human population density is high in coastal areas and is predicted to continue to increase, the associated impacts of changing hydrology, nutrient fluxes, and sediment fluxes (to name a few) are expected to be substantial, at least in the near-shore zone. In addition, both climate and land use have the potential of altering the air-sea partitioning of $\mathrm{CO}_{2}$, which may then feed back on climate.

Coastal carbon modeling systems range from box models (e.g., Walsh 1988) (Table 1) to 3D, coupled circulation-biogeochemical models (e.g., Moll 1998, Fennel et al. 2006, Arrigo et al. 2008, Liu \& Chai 2009, Druon et al. 2010) (Table 2). Similarly, representation of the biogeochemical processes ranges from nutrient-phytoplankton-zooplankton aggregate formulations to multifunctional group representations of the ecosystem (e.g., Le Quéré et al. 2005, Hood et al. 2006, Lehmann et al. 2009). As emphasis is placed on understanding the role of continental shelf systems in carbon budgets under changing patterns of climate and land use, coupled-model systems will be used more often to provide projections of future states resulting from these changes. However, the choice of a model and its formulations are dependent on the problem that is being addressed, which places important constraints on the model results. Thus, it is appropriate to consider the limitations in understanding of carbon cycling in continental margin systems that impede the development of realistic models of this process. 

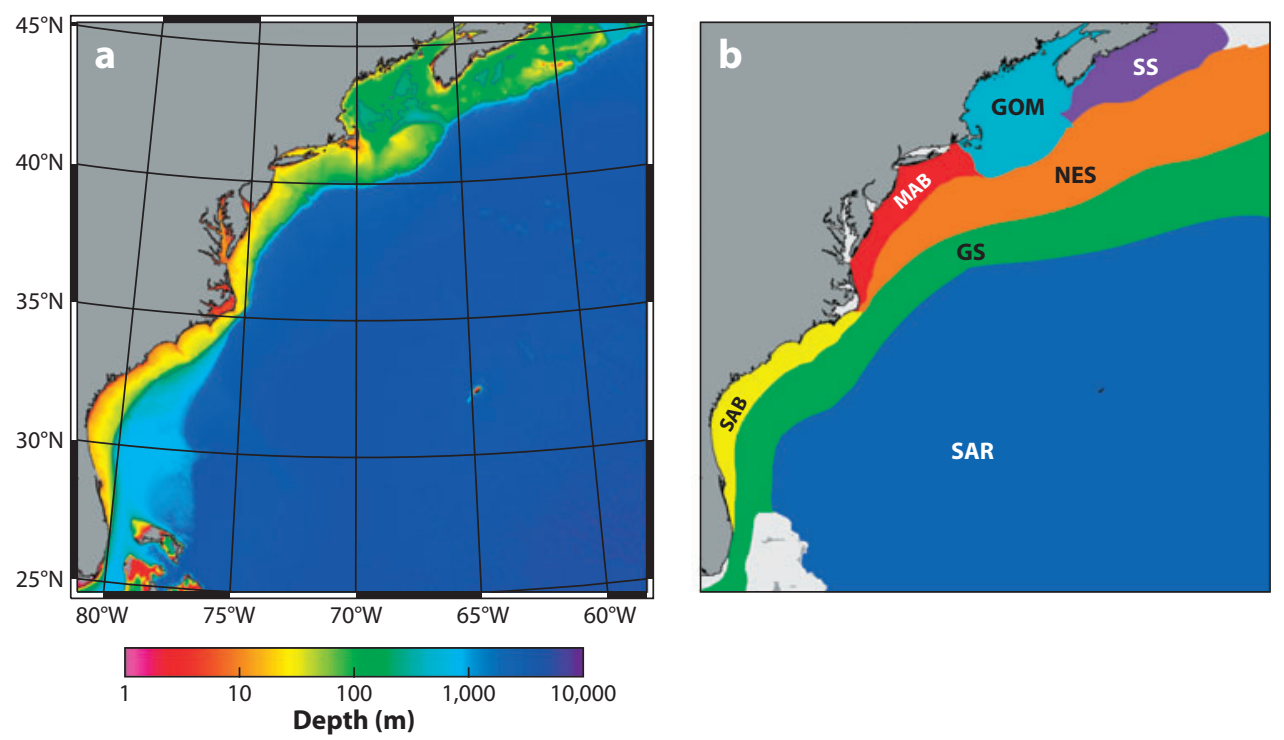

Figure 2

(a) Bathymetry map for the U.S. eastcoast region included in the northeastern North American (NENA) model domain. The 200-m isobath (gray line) denotes the continental shelf edge. (b) Subareas of the NENA model domain used for analysis of model results. Abbreviations: GOM, Gulf of Maine; GS, Gulf Stream; MAB, Middle Atlantic Bight; NES, Northeast Slope; SAB, South Atlantic Bight; SAR, Sargasso Sea; SS, Scotian Shelf.

The objective of this paper is to provide an overview of the current state of carbon-cycling modeling for continental margin systems and the processes and issues that potentially provide the next challenges to such models. This is done within the context of a model developed for the northeastern North American (NENA) shelf region (Figure 2), which is perhaps one of the best-studied continental shelf regions. The NENA model includes a high-resolution circulation model and a detailed biogeochemical model of coastal carbon and nutrient cycling (Figure 3). This coupled-modeling framework has been used to investigate the role of sediment denitrification as a nutrient sink (Fennel et al. 2006) and the controls on air-sea carbon fluxes on the NENA continental shelf (Fennel et al. 2008). Additional studies with the NENA model have provided estimates of cross-shelf export of particulate organic carbon (Fennel \& Wilkin 2009) and an evaluation of the role of dissolved organic matter (DOM) dynamics in coastal ocean biogeochemical cycling (Druon et al. 2010). Results from these studies are described more fully in a later section.

The controls on carbon cycling on continental shelves are next discussed as a basis for describing the approaches used to represent these in the NENA model. Sample simulations from the NENA model are then used to illustrate the consequences of particular choices of forcing and initial fields. Quantitative statistical metrics are used to highlight differences in simulated and observed distributions of sea surface temperature and chlorophyll. Limitations of the data sets used to evaluate coupled models are described and results from simulations that used different forcings and parameterizations are compared to illustrate model sesnsitivity. The final section provides a discussion of the challenges that limit the ability to simulate carbon cycling on continental shelves as a basis for directing future research programs. 
Nitrogen cycle

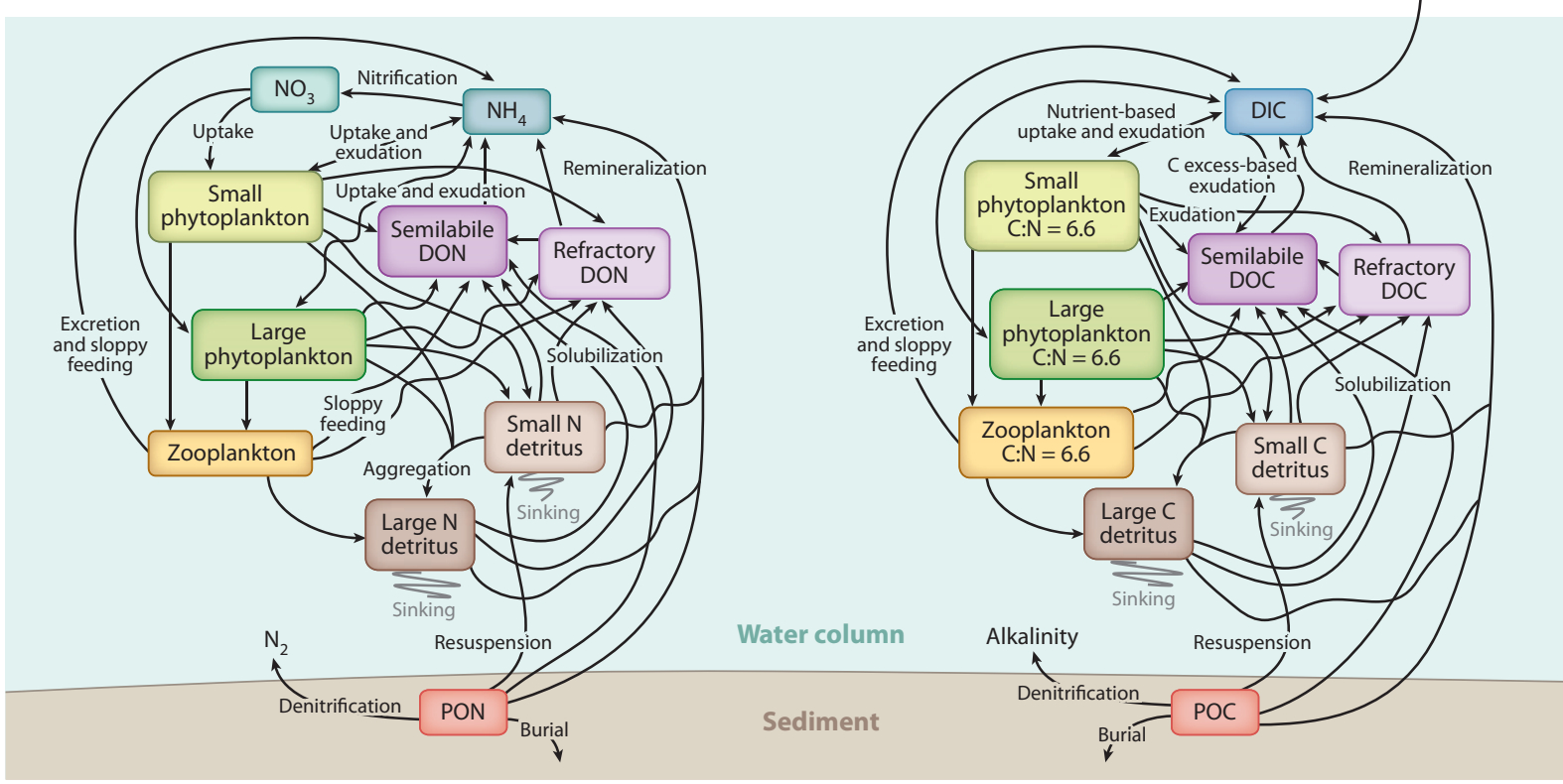

Figure 3

Schematic of the internal and boundary processes included in the biogeochemical component of the northeastern North American (NENA) model. Details of the biogeochemical model are derived from Fennel et al. $(2006,2008)$ and Druon et al. (2010). Abbreviations: DIC, dissolved inorganic carbon; DOC, dissolved organic carbon; DON, dissolved organic nitrogen; POC, particulate organic carbon; PON, particulate organic nitrogen.

\section{CONTROLS ON SHELF CARBON CYCLING}

Modeling shelf carbon cycles requires knowledge of the many processes that control the flow of organic and inorganic carbon in and out of the shelf system; these include exchanges with the open ocean, land, air, and sediment. Understanding mechanisms of internal cycling on the continental shelf is also needed to predict how exchange processes will vary over time. Moreover, key to development of a useful model is the ability to determine the rates and processes that have the largest impact on the relevant carbon pools and their flows. For example, studies of the impact of synoptic weather events and coastal bathymetry on primary production and air-sea $\mathrm{CO}_{2}$ flux in upwelling systems likely require $2 \mathrm{D}$ or $3 \mathrm{D}$ models that include nutrients, phytoplankton, and carbonate chemistry. A sedimentary component for such a model may not be needed. However, if the research questions focus on controls on the carbon budget of continental shelves from decades to millennia, then sediment interactions play a critical role and must be included, probably at the expense of spatial resolution and ecosystem complexity. The choices to be made in modeling carbon cycling on continental shelves require at least a preliminary evaluation of inputs of sediment, nutrients, fresh water, carbon from land, elemental fluxes between the sediments and the water column, air-sea fluxes of gases and nutrients, internal cycling in the water column (e.g., primary production and respiration), and cross-shelf exchange. The strong linkages between and among these key processes that control organic and inorganic carbon cycles in the coastal ocean (Figure 4) underscore the importance of correctly representing these in models. 


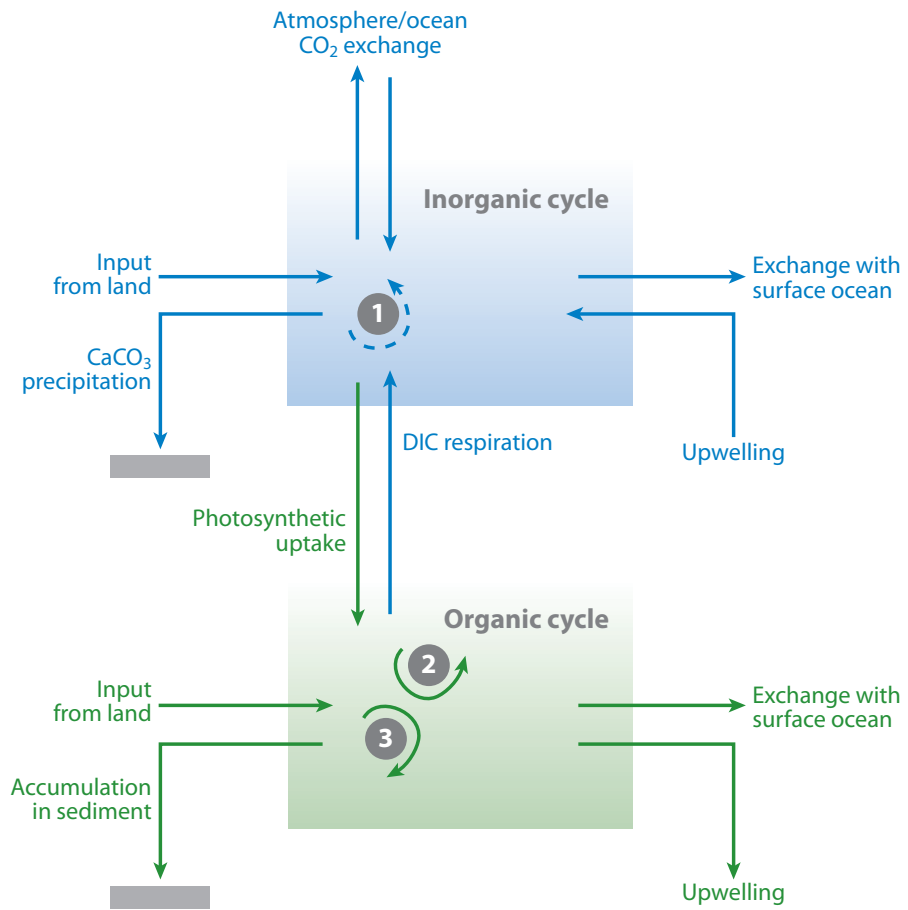

Figure 4

Simple box model showing linkages and interactions between organic and inorganic carbon cycles in coastal waters. Inorganic and organic carbon undergo internal transformations that modify exchanges with the atmosphere, surface ocean, and sediments. Curved arrow 1 indicates $\mathrm{CO}_{2}$ release by $\mathrm{CaCO}_{3}$ precipitation; curved arrows 2 and 3 indicate remineralization of organic carbon produced in situ and brought in from land that contributes to inorganic carbon (DIC) production. Adapted from Mackenzie et al. (2004).

Mackenzie et al. (2004) suggested that mineralization of land-derived organic matter and calcium carbonate $\left(\mathrm{CaCO}_{3}\right)$ precipitation are major controls on $\mathrm{CO}_{2}$ flux across the air-sea boundary, and that the increase in $\mathrm{CO}_{2}$ due to fossil fuel combustion has changed the direction of these air-sea fluxes since the beginning of the industrial revolution. In addition, the coastal ocean is believed to have changed from being net heterotrophic $\left(\mathrm{CO}_{2}\right.$ source) in preindustrial times (Smith \& Hollibaugh 1993, Wollast \& Mackenzie 1989) to the present situation of net autotrophy (Ducklow \& McCallister 2005). Such changes make it imperative to develop predictive models of the shelf carbon cycle. Below, some of the basic processes involved in exchange and internal transformations of nutrients and carbon in continental shelf regions are summarized.

\section{Land-Ocean Boundary}

Of major importance to the shelf carbon cycle are inputs from rivers and submarine groundwater discharge of suspended solids, colored dissolved material, alkalinity, and organic and inorganic forms of carbon and nutrients. These inputs greatly affect stratification, light availability, and biogeochemical transformations in the coastal zone.

Alkalinity and dissolved inorganic carbon (DIC) inputs alter the speciation of inorganic carbon and thus $p \mathrm{CO}_{2}$ of surface waters, which influences air-sea exchange of $\mathrm{CO}_{2}$. Organic carbon and nutrient inputs stimulate the biogeochemical processes of photosynthesis and respiration, 
which lead to additional impacts on exchange of $\mathrm{CO}_{2}$ with the atmosphere and alters the oxygen distribution and denitrification (Sarmiento \& Gruber 2006, p. 102). The quality of organic material delivered from land is of utmost importance, as it determines the time scale for remineralization of this material. Of particular relevance is the ratio of the remineralization time scale to the residence time of water on the continental shelf, as this will determine the fraction of riverine material that is ultimately exported to the open ocean.

Watershed geomorphology, climate, and land use result in large spatial and temporal variations in riverine flows and concentrations of river-borne material, leading to large uncertainties in estimates of loading to coastal regions in all but the most extensively monitored watersheds. Even more challenging is the quantification of submarine groundwater discharge, which includes freshwater and seawater that has circulated through the sediments and requires estimates of the volume flux and groundwater constituent concentrations (Moore 2010). Radioisotope analysis (Moore et al. 2008) estimated that submarine groundwater discharge is comparable to riverine discharge for the Atlantic Ocean, implying that this is an important source that needs to be included in coastal carbon models.

\section{Air-Sea Boundary}

The air-sea boundary has two important effects on coastal carbon cycling through mediation of the exchange of important gases, including $\mathrm{CO}_{2}$ and oxygen, and deposition of nitrogen, which is often the limiting nutrient in coastal systems. Carbon dioxide and oxygen cross the air-sea interface mainly by diffusion, which is controlled by the air-sea gradient in the gas partial pressure, the gas solubility (which depends on temperature and salinity), and near-surface turbulence (Sarmiento \& Gruber 2006, p. 82). Atmospheric $p \mathrm{CO}_{2}$ varies on synoptic, seasonal, and interannual time scales, mainly as a result of weather systems, fossil fuel burning, and large-scale exchanges with the terrestrial biosphere and ocean; in contrast, atmospheric oxygen is essentially constant. Surface ocean $p \mathrm{CO}_{2}$ is governed by the concentrations of DIC and alkalinity, which themselves are influenced by riverine input, circulation, and internal cycling (e.g., photosynthesis, respiration, calcification, and $\mathrm{CaCO}_{3}$ dissolution). Near-surface turbulence that reduces the resistance to gas exchange is generated by winds and waves but inhibited by surfactants and viscosity. The production of bubbles by breaking waves and their subsequent injection and collapse in the surface-ocean mixed layer is an additional mechanism by which $\mathrm{CO}_{2}$, and especially oxygen, may be exchanged with the atmosphere.

Enrichment of the sea surface microlayer with dissolved organic carbon (DOC) and particulate organic carbon (POC), as well as living organisms (plankton, bacteria, viruses), affects physical and chemical properties at the air-sea interface and thus influences exchange processes across the air-sea boundary (Liss \& Duce 1997, Frew et al. 2002). Microlayer enrichment results from a combination of processes, such as input from bubble scavenging and biological production; loss from diffusion, aerosol production, and biological degradation; stabilization by surface tension; and exchanges between dissolved and particulate pools (Liss \& Duce 1997). Water and air temperatures influence the rates of many biological processes as well as the intensity of evaporation at the airwater interface. Wind mixes the microlayer with seawater in the upper mixed layer, thus reducing enrichment. Ultraviolet radiation can alter the composition of dissolved organic matter by breaking down refractory compounds and producing smaller, more labile ones (Mopper \& Kieber 2000). The sea surface microlayer is thus a complex interface that plays an important role in air-sea exchange.

Atmospheric deposition is increasingly recognized as a significant source of nitrogen that influences marine productivity and other biogeochemical processes, particularly in coastal areas. 
Atmospheric nitrogen reaches the ocean through precipitation (wet deposition) and through direct contact of air with the surface (dry deposition) (Spokes et al. 2000). Wet deposition is mainly in the form of nitrate $\left(\mathrm{NO}_{3}{ }^{-}\right)$, ammonium $\left(\mathrm{NH}_{4}{ }^{+}\right)$, and organic nitrogen and usually exceeds dry deposition (mainly as $\mathrm{NO}, \mathrm{NO}_{2}, \mathrm{HNO}_{3}$, and $\mathrm{NH}_{3}$ ) over long time periods. The sources of reactive nitrogen deposited to the ocean are largely anthropogenic, resulting ultimately from emission of NO (leading to nitrate deposition), which is mainly from the burning of fossil fuels and biomass, and $\mathrm{NH}_{3}$ (leading to $\mathrm{NH}_{4}{ }^{+}$deposition), which is mainly from animal husbandry, soils, and biomass burning. Atmospheric organic nitrogen cycling is poorly understood, and there may be substantial artifacts in measuring rainwater-dissolved organic nitrogen (DON; Keene et al. 2002), but current estimates suggest that roughly $30 \%$ of the reactive nitrogen deposition to the ocean is organic (Cornell et al. 2003, Jickells 2006). Using atmospheric models, Duce et al. (2008) estimated reactive nitrogen deposition to the ocean in 2000 to be more than three times the deposition in 1860, with changes being greatest in the coastal waters that receive most of the anthropogenic nitrogen deposited on the ocean.

The contribution of atmospheric deposition to coastal nitrogen budgets is substantial. For example, modeling and observational studies estimate that atmospheric nitrogen deposition is $10-50 \%$ of upwelled nitrogen or new production over large areas downwind of populated regions (Duce et al. 2008, Guerzoni et al. 1999, Krishnamurthy et al. 2007, Onitsuka et al. 2009). Regional budget approaches for many coastal seas (Jickells 2006, Loye-Pilot et al. 1990, Paerl et al. 2002) show that atmospheric deposition of nitrogen is comparable and can often exceed riverine inputs.

More subtle effects of atmospheric deposition on marine biogeochemical processes may also occur. For example, the N:P deposition ratio differs substantially from the Redfield ratio, often greatly exceeding it, mainly because the atmospheric cycle of phosphorus has been much less perturbed than that of nitrogen (Jickells 2006). Furthermore, atmospheric deposition of nitrogen and sulfur may contribute substantially to the acidification of coastal waters (Doney et al. 2007).

\section{Sediment-Water Boundary}

Adequate representation of fluxes across the sediment-water interface is crucial for shelf applications, where a significant fraction of organic matter remineralization and oxygen consumption occurs in the sediment. Remineralization pathways are qualitatively different in the sediment compared with the water column. For example, anaerobic processes of denitrification, sulfate reduction, and anammox (ANaerobic AMMonium OXidation, i.e., the bacterial conversion of nitrate and ammonium into $\mathrm{N}_{2}$ gas; see Kuypers et al. 2005) occur in anoxic waters and sediment layers and have different stoichiometries relative to aerobic remineralization in oxic waters and sediment. Also, the sediment can act as a permanent repository of carbon through burial of organic matter and $\mathrm{CaCO}_{3}$, and a loss of nitrogen through denitrification and anammox. Both processes represent potential major sinks for fixed nitrogen and thus limit oceanic primary productivity in waters with strong oxygen minima and strongly reducing sediments. However, the extent and importance of anammox relative to denitrification remains uncertain (Ward et al. 2009).

Organic matter mineralization and nutrient cycling in sediments are controlled primarily by microbial processes, but benthic macrofauna can greatly affect the rates of these processes by altering the physical, chemical, and biological properties of the sediment (e.g., Rhoads 1974, Aller 1988). Bioturbation can mix particles by the building of tubes and burrows, and bioirrigation can increase flow through the sediment, both of which affect redox conditions and exchange of material across the sediment-water boundary (Aller 1994, Kristensen 2000). Macrobenthos may also play a significant role in filtering particles from the overlying water column, although the extent of this is controversial (Pomeroy et al. 2006). Much of the research on sediment biogeochemistry has been 
carried out in muddy, cohesive sediments, but the continental shelf includes large areas of sandy, noncohesive sediments with different exchange processes and rates (Huettel et al. 1996, 1998). It is now clear that pore-water advection is an important influence on biogeochemical processes in permeable sediments (Reimers et al. 2004).

Sedimentation rates, which can be high in shelf regions, can greatly impact organic carbon remineralization rates as high sedimentation rates reduce the length of time that organic matter is exposed to oxygen and bioturbation, thus increasing the efficiency of organic carbon preservation (Henrichs \& Reeburgh 1987, Hartnett et al. 1998, Kristensen 2000). High sedimentation rates also often result from high inputs of terrestrial material with refractory organic matter that is preferentially buried.

\section{Internal Carbon Cycling}

Many biogeochemical transformations that affect the carbon cycle occur within the shelf water column, particularly with regard to production and transformation among pools of DOC, DIC, POC, and particulate inorganic carbon (PIC). Metabolism of organic matter is particularly high in the coastal ocean due to the large inputs of both land-derived organic matter and primary production, which promote microbial and higher trophic level remineralization of organic carbon to DIC (Smith \& Hollibaugh 1993, Gattuso et al. 1998). High levels of suspended sediments from riverine contributions and resuspension of bottom sediments enhance sorption/desorption processes between organic matter and mineral matrices (Keil et al. 1997, Komada \& Reimers 2001, Komada et al. 2002). Nutrient uptake and recycling is enhanced in coastal waters due to the shallow water column and storm events that redistribute recycled nutrients at depth to the euphotic zone (Dagg et al. 2004). Zooplankton grazing can accelerate the vertical flux of POC to the sediment (Honjo et al. 2008) and recycling of carbon and nutrients within the water column (Calbet \& Landry 2004, Dagg et al. 2004). However, vertical flux of POC is difficult to measure in the energetic waters of the coastal zone and has not been well characterized in these regions.

Net ecosystem production (NEP) of DOC contributes approximately $20 \%$ of total primary production (e.g., Hansell \& Carlson 1998, Álvarez-Salgado et al. 2001) and 20-50\% of the DOC in the coastal ocean. Primary production and NEP of DOC are not widely measured in continental margins, which contributes to underestimation of total primary production and NEP in the coastal ocean. The DOM concentrations on continental shelves are elevated and contain a higher labile fraction than DOM in deep-slope waters, where carbon is more refractory and is enriched relative to Redfield ratios of nitrogen and phosphorus (Hopkinson et al. 2002). Although the half-lives of the labile DOM pool are on the order of shelf-water residence time, a substantial pool of DOM that is depleted in nitrogen and phosphorus relative to carbon remains in the shelf water and could be exported by advective and eddy diffusive processes (Hopkinson et al. 2002). Almost half of the global biological-pump transfer of organic carbon to the deep ocean occurs on continental margins (Jahnke 2010). Over 40\% of the marine PIC production in the form of calcium carbonate occurs in the coastal ocean, including coral reefs and carbonate shelves (Milliman 1993, Gattuso et al. 1998). Ocean acidification will likely reduce PIC production and accelerate the dissolution of carbonate substrates within coastal waters.

\section{THE NORTHEASTERN NORTH AMERICAN MODEL}

The NENA model was developed to investigate the transport and cycling of carbon and nitrogen to and within the U.S. east coast coastal ocean margin and the impact of climate variability, climate change, and land-cover/land-use change on these fluxes (Hofmann et al. 2008). NENA is 
based on the Regional Ocean Modeling System (ROMS) and its biogeochemical module. ROMS is widely used for shelf circulation and coupled physical-biological applications (e.g., Dinniman et al. 2003; Lutjeharms et al. 2003; Marchesiello et al. 2003; Peliz et al. 2003; Fennel et al. 2006, 2008; Wilkin 2006). The ROMS computational kernel (Shchepetkin \& McWilliams 1998, 2003, 2005) produces accurate evolution of tracer fields, which is a particularly attractive feature for biogeochemical modeling because it facilitates accurate interaction among tracers and accounting of total nutrient and carbon budgets.

The NENA model domain (Figure 2) encompasses the entire U.S east coast continental shelf, which presents a number of challenges in terms of model complexity, boundaries, and resolution. There are 31 rivers represented along the land-ocean boundary, complex open boundaries that include subtropical and subpolar regions of the Atlantic Ocean and a significant shelf area where sediment-water interactions play an important role (e.g., Fennel et al. 2006). The configuration of the NENA model for this region uses a $10-\mathrm{km}$ horizontal resolution and 30 terrain-following vertical levels stretched to give high resolution in surface and bottom boundary layers. This is sufficient to capture the dominant dynamics governing shelf-wide circulation. Open boundary temperature, salinity, and subtidal frequency velocity are taken from 5-day averages of the HYbrid Coordinate Ocean Model (HYCOM) data assimilation product developed as part of the Global Ocean Data Assimilation Experiment North Atlantic Basin "best-estimate" analysis for 2003 to the present (Chassignet et al. 2007). Tides are introduced at the boundary using harmonic data from the Oregon State University Topex/Jason altimeter data inversion (Egbert \& Erofeeva 2002) and a surface gravity wave radiation scheme (Flather 1976). Air-sea heat and momentum fluxes are computed using bulk formulae (Fairall et al. 2003) applied to model sea surface conditions. Air temperature, pressure, humidity, radiation, precipitation, and winds are from 3-hour averages of National Center for Environmental Prediction North American Regional Re-analysis available from 1979 to the present. Vertical turbulent mixing closure uses the parameterization of Mellor \& Yamada (1982) and Warner et al. (2005). A summary of the choices made in configuring the NENA model is given in Table 3. The following sections provide more details on the biogeochemical configuration choices and discussions and examples of the relative merits and limitations of some of these choices.

\section{Land-Ocean Boundary}

Coastal oceans and marginal seas receive inputs of freshwater, suspended mineral particles (terrigenous sediment), organic matter, and inorganic solutes (nutrients, dissolved carbon) from rivers and groundwater discharge. In numerical models, these inputs can be represented as point or line sources, but obtaining accurate time-series estimates of these inputs in order to force simulation models is difficult. Deriving accurate freshwater discharges at river mouths from measurements at upstream gauges is challenging because adjustments specific to each watershed are required to account for ungauged flow. In the NENA model, a climatology based on United States Geological Survey gauging data (see Table 3 for details) is used to specify freshwater inputs.

In addition to freshwater discharges, the concentrations of dissolved and particulate constituents in these waters have to be specified, e.g., nitrate, ammonium, DOC, POC, particulate organic nitrogen (PON), and others. Some variables, such as nutrients, are measured regularly at gauging stations, and sufficient measurements exist to construct a climatology. Other variables, however, are rarely or never measured, and thus it is simply assumed, as in the NENA model, that river concentrations are time-invariant. This precludes inclusion of temporal variations in concentration, such as those that occur after heavy rain events. The effects of such events likely depend on the type of watershed, e.g., urban versus agricultural areas. Groundwater discharge 
Table 3 Summary of approaches used to specify initial conditions, boundary values, and processes and forcing for internal carbon and nutrient transformations for the northeastern North American model that used high-resolution forcing fields

\begin{tabular}{|c|c|c|}
\hline Boundary & Process & Treatment \\
\hline \multirow[t]{4}{*}{$\begin{array}{l}\text { Open boundaries and } \\
\text { initial conditions }\end{array}$} & Tides & $\begin{array}{l}\text { Harmonic data from the Oregon State University TOPEX/ } \\
\text { Jason altimeter data inversion (Egbert \& Erofeeva 2002); } \\
\text { surface gravity wave radiation scheme (Flather 1976) }\end{array}$ \\
\hline & $\begin{array}{l}\text { Temperature, salinity, subtidal } \\
\text { frequency velocity }\end{array}$ & $\begin{array}{l}\text { 5-day averages of the HYCOM data assimilation product } \\
\text { developed as part of the Global Ocean Data Assimilation } \\
\text { Experiment, North Atlantic Basin, "best- } \\
\text { estimate" analysis for } 2003 \text { to present (Chassignet et al. 2007) }\end{array}$ \\
\hline & \multirow[t]{2}{*}{ Biogeochemistry } & $\begin{array}{l}\text { NODC climatology for } \mathrm{NO}_{3} \text { based on World Ocean Atlas } \\
\text { data (Conkright et al. 2002); TIC based on Lee et al. (2000); } \\
\text { alkalinity based on Millero et al. (1998) }\end{array}$ \\
\hline & & $\begin{array}{l}\text { Nudging of biogeochemistry using temperature-salinity } \\
\text { relationships at the boundaries }\end{array}$ \\
\hline \multirow[t]{2}{*}{ Air-sea } & Air-sea heat and momentum fluxes & $\begin{array}{l}\text { Bulk formulas (Fairall et al. 2003) applied to model sea surface } \\
\text { conditions. Air temperature, pressure, humidity, radiation, } \\
\text { precipitation, and winds are from 3-h NCEP North } \\
\text { American Regional Re-analysis (NARR) fields (Mesinger } \\
\text { et al. 2006), available from } 1979 \text { to present }\end{array}$ \\
\hline & $\mathrm{CO}_{2} / \mathrm{O}_{2}$ gas exchange & Wanninkhof 1992 \\
\hline \multirow[t]{3}{*}{ Internal transformations } & Biological model & Nitrogen cycle model (Fennel et al. 2006, 2008, 2009) \\
\hline & Light & $\begin{array}{l}\text { Photosynthetically active radiation (PAR) from empirical } \\
\text { correlation between SeaWiFS-derived PAR and NARR } \\
\text { shortwave radiation }\end{array}$ \\
\hline & Carbon model & OCMIP standard for carbonate system \\
\hline$\underline{\text { Sediment-water }}$ & Denitrification & Fennel et al. 2006 \\
\hline \multirow[t]{2}{*}{ Land-ocean } & Freshwater discharge & $\begin{array}{l}\text { Climatology average derived from USGS gauge data and } \\
\text { adjusted by a scale factor to account for ungauged parts of } \\
\text { individual river watersheds (J.R. Moisan, unpublished data) }\end{array}$ \\
\hline & Dissolved and particulate constituents & Total nitrogen in nitrate pool (Howarth et al. 1996) \\
\hline
\end{tabular}

Abbreviations: HYCOM, Hybrid Coordinate Ocean Model; NCEP, National Centers for Environmental Prediction; NODC, National Oceanographic Data Center; OCMIP, Ocean Carbon-Cycle Model Intercomparison Project; SeaWiFS, Sea-viewing Wide Field-of-view Sensor; USGS, United States Geological Service.

is also poorly quantified and typically not accounted for in models but may represent significant sources of freshwater, nutrients, and other constituents (Slomp \& Capellen 2004, Moore 2010).

An alternative to observation-based specification of river inputs of nutrients and particulates is to use output from hydrological watershed models (e.g., Dumont et al. 2005, Donner et al. 2002). These models generally provide integrated annual or seasonal values by watershed and do not represent temporal variability on shorter time scales. Recently, progress has been made in the hydrological modeling community in this respect. Higher temporal and spatial resolution is now suitable for coupling with coastal ocean models (Tian et al. 2009, Liu et al. 2008), and the NENA model is now being expanded to couple with these models.

Additional uncertainties arise from biogeochemical transformations that occur in wetlands, marshes, and estuaries, which alter nutrient loadings between the point of freshwater river 
discharge and the coastal ocean. Although estuaries may be included in the model domain, e.g., Chesapeake Bay in the NENA model, estuarine transformation processes may not be fully accounted for if the model resolution is insufficient to represent vertical mixing or estuarine circulation dynamics that affect residence time. Furthermore, benthic processes that are of lesser importance in the open coastal seas, yet might be significant in enclosed estuarine waters, are commonly omitted from biogeochemical models tailored to the shelf sea ecosystem.

Some river constituents (state variables) and biogeochemical processes may not be considered in the shelf models at all, yet may have important roles. For example, high loads of terrigenous sediment in river plumes can increase light attenuation, thus trapping heat at the surface and limiting photosynthetic production of organic matter. Within the NENA domain, it has been shown (Cahill et al. 2008) that realistic modeling estimates of the amount and fate of POC, which results from high Hudson River discharge events onto the Middle Atlantic Bight (MAB) shelf, require variable light-attenuation as well as feedbacks from biological production to the heat fluxes in the upper water column.

\section{Air-Sea Boundaries}

Standard parameterizations for air-sea gas exchange of $\mathrm{CO}_{2}$ and oxygen (e.g., Wanninkhof 1992, Nightingale et al. 2000) are typically used in models to specify this flux, but uncertainties about their general applicability remain, and some processes are not well represented, e.g., supersaturation of oxygen by bubbles (D'Asaro \& McNeil 2007). The NENA model uses the standard parameterization given in Wanninkhof (1992) (Table 3). Although nitrogen deposition may be an important process in the region (see discussion above), rates are not yet well enough known to include in the NENA model.

\section{Sediment-Water Boundary}

Sediment denitrification (i.e., the removal of fixed nitrogen parameterized as described above) has important consequences for the internal transformations of shelf systems, e.g., primary production, and leads to a counterintuitive interaction between nitrogen and carbon cycling processes on the shelf. Denitrification lowers the availability of fixed nitrogen, which in turn reduces the photosynthetic fixation of inorganic carbon into organic matter, which should decrease the oceanic uptake of $\mathrm{CO}_{2}$. However, sediment denitrification produces alkalinity, which will promote uptake of atmospheric $\mathrm{CO}_{2}$. The generation of alkalinity is typically associated with the dissolution of calcium carbonate, which mostly occurs below the lysocline in the deep ocean; however, several anaerobic remineralization processes that occur in sediments on continental shelves generate alkalinity as well (Chen 2002).

The highest level of benthic-pelagic interaction in a biogeochemical model is a two-way, coupled water column-sediment model (Soetaert et al. 2000), but few biogeochemical models include this two-way coupling. Models for shelf seas typically parameterize benthic-pelagic coupling in simple ways. In the NENA model, on the basis of observations by Seitzinger \& Giblin (1996), denitrification is assumed to be proportional to the sediment oxygen demand required to oxidize the modeled flux of particulate matter to the seabed. An alternative is to derive parameterizations by means of meta-analyses of diagenetic models as described in Middelburg et al. (1996) and Soetaert et al. (2000). Comparison of the meta-model parameterization in Middelburg et al. (1996) against a large coastal data set of nitrogen fluxes across the sediment-water interface showed large discrepancies, indicating that the meta-analyses of diagenetic models should be validated regionally with available observations (Fennel et al. 2009). 


\section{Internal Transformations}

The present configuration of the NENA model contains one phytoplankton component and so does not allow simulation of seasonally dependent effects in phytoplankton production arising from changing community composition. Also, simulation of the timing and magnitude of blooms is limited by inclusion of a single phytoplankton component. For these reasons, the NENA model is being reconfigured to include more than one phytoplankton component (Figure 3).

Similarly, the ability to explicitly simulate changes in the semilabile DOM pool is critical to understanding the internal cycling of carbon and nutrients on the shelf. This capability is now included in the NENA model (Druon et al. 2010) (Figure 3).

In the NENA model, alkalinity is initialized as a function of salinity because its distribution follows that of salinity to first order (Millero et al. 1998). However, in coastal regions, humic materials (Cai et al. 1998), dissolved organic matter (Hernandez-Ayon et al. 2007), and microorganisms (Kim et al. 2006) can become significant contributors to measured alkalinity. Where humic substances and organic bases produced by phytoplankton are important but not recognized, calculation of $p \mathrm{CO}_{2}$ and the resulting $\mathrm{CO}_{2}$ flux estimates will be in error. The current configuration used for the NENA model is based on point-source, monthly climatological estimates for river outflow, which does not include these effects and, as a result, potentially introduces a bias in $\mathrm{CO}_{2}$ flux estimates. Efforts are under way to incorporate high temporal and spatial resolution output as it becomes available from hydrological watershed models suited to coupling with coastal ocean models.

Seasonal relationships between total inorganic carbon (TIC) and sea surface temperature (SST) were developed for regions around the world (Lee et al. 2000) using measurements made during the late 1980s and early 1990s as part of the Joint Global Ocean Flux Study. However, these data sets are now 20 years old and do not reflect recent changes in riverine freshwater inputs, changes resulting from ice melt at high latitudes, and changes in ocean acidification. Data sets and approaches for the development of new parameterizations that include these effects are needed to undertake simulations of the effects of climate variability on carbon cycling in continental shelf waters.

\section{Initial Fields and Boundary Conditions}

Continental shelf models are regional in scope and therefore include open boundaries, which demands that oceanic conditions beyond the model domain be prescribed from data and/or results from a larger-scale model. Where large-scale biogeochemical models are available, this can be done for biological variables as well, or it may be necessary or preferable to prescribe open-boundary biological variables based on climatological data. Our experience with NENA simulations shows that nutrients, oxygen, TIC, and alkalinity are the critical variables in determining simulation results and hence require the most care in specification of initial and boundary values. Phytoplankton and zooplankton biomass and detritus are less critical because the adjustment scales for these variables in the NENA model (and others) are relatively short ( $\sim-10$ days).

Boundary estimates for nitrate, TIC, alkalinity, and oxygen are important to the accuracy and robustness of the simulation results, and these vary both regionally and, in the upper mixed layer, seasonally. Some of this variability is captured by using the property-property relationships that exist between nitrate, TIC, and alkalinity and physical variables such as temperature and salinity. However, these relationships are region-specific (Lee et al. 2000, Millero et al. 1998, Koeve 2001) and do not necessarily apply over the entirety of the model domain. The nitrate-temperature relationships used in the NENA model were derived from World Ocean Atlas data (Conkright et al. 2002) and account for regional differences in the subpolar and subtropical regions but do 
not necessarily describe nutrient distributions adequately on the continental shelf. Attempts to resolve along- and across-shelf gradients are under way, and some improvement in biological state estimates has been realized by accounting for these gradients.

At the open boundaries of the NENA domain (Figure 2), the biogeochemical variables are constrained by nudging within a buffer zone. Nudging refers to the relaxation of model estimates to predetermined values. For the NENA model simulations, conditions along the open boundaries were specified using temperature and salinity values obtained from the HYCOM (Chassignet et al. 2007), with nitrate, TIC, alkalinity, and oxygen fields derived from the property-property relationships described above (Table 3). All other biogeochemical variables are nudged to small constant values.

\section{Effect of Initial and Forcing Fields}

Significant advances have been made in the last 10 years on the availability of reliable estimates of physical variables from basin-scale forecast models. Using higher spatial and temporal resolution products to initialize and force the model can considerably improve ocean state estimates. For example, comparisons of satellite-derived SST distributions from 2004 (Figure 5a) with simulated SST from two NENA simulations, which were initialized and forced differently (Figure $\mathbf{5} \boldsymbol{b}, \boldsymbol{f}$ reflects lower-resolution forcing and earlier versions of initial condition fields; Figure $\mathbf{5} \boldsymbol{d}, \boldsymbol{g}$ reflects higher-resolution forcing and conditions shown in Table 3), show improvement, as measured by statistical comparisons, that can be attributed to better resolution in the initial and forcing fields. The improved resolution of the forcing fields (Figure $5 \boldsymbol{d}$ ) resulted in many cases in substantially better comparisons with satellite-derived SST than those obtained for the lower-resolution simulation (Figure $5 \boldsymbol{b}$ ). The scatter in the SST frequency distribution was reduced, and differences in simulated and observed SST were confined mostly to the region influenced by variability in the Gulf Stream location.

These changes in initial and forcing fields also had a small but significant effect on the ability of the model to reproduce the annual SST cycle. Target diagrams (Joliff et al. 2009) provide a quantitative means for assessing the effect of changes in initial and forcing fields on the SST simulation. These diagrams were constructed for each of the seven subregions (Figure 2) to assess spatial dependency of the model SST skill. Within the Northeast Slope region, there was very little change between the two simulations; however, in the SAB, SST was underestimated using the original forcing fields (Figure $6 \boldsymbol{a}$ ) and overestimated using the updated fields (Figure $6 \boldsymbol{b}$ ). Similarly, for the Scotian shelf, seasonal variability was underestimated in the original simulation but overestimated in the updated simulation. The general pattern emerging from the target diagrams is that the new forcing fields resulted in a slightly more positive bias in the simulated SST for the primary continental shelf region (MAB, SAB, and Gulf of Maine), which is of similar sign in each of these subregions.

These changes in forcing fields had a relatively small effect on surface chlorophyll concentrations. Simulated surface-chlorophyll concentrations were instead more sensitive to the choice of initial nitrate conditions used in the simulation. The original nitrate initial conditions used did not include sufficiently large cross-shelf concentration gradients. When these initial conditions were made more realistic, the improvement in model-data fit in terms of surface chlorophyll was significant throughout the entire simulation and throughout the entire model domain (Figure 7). This illustrates the importance of generating appropriate initial nutrient fields in coastal carbon cycling models. 

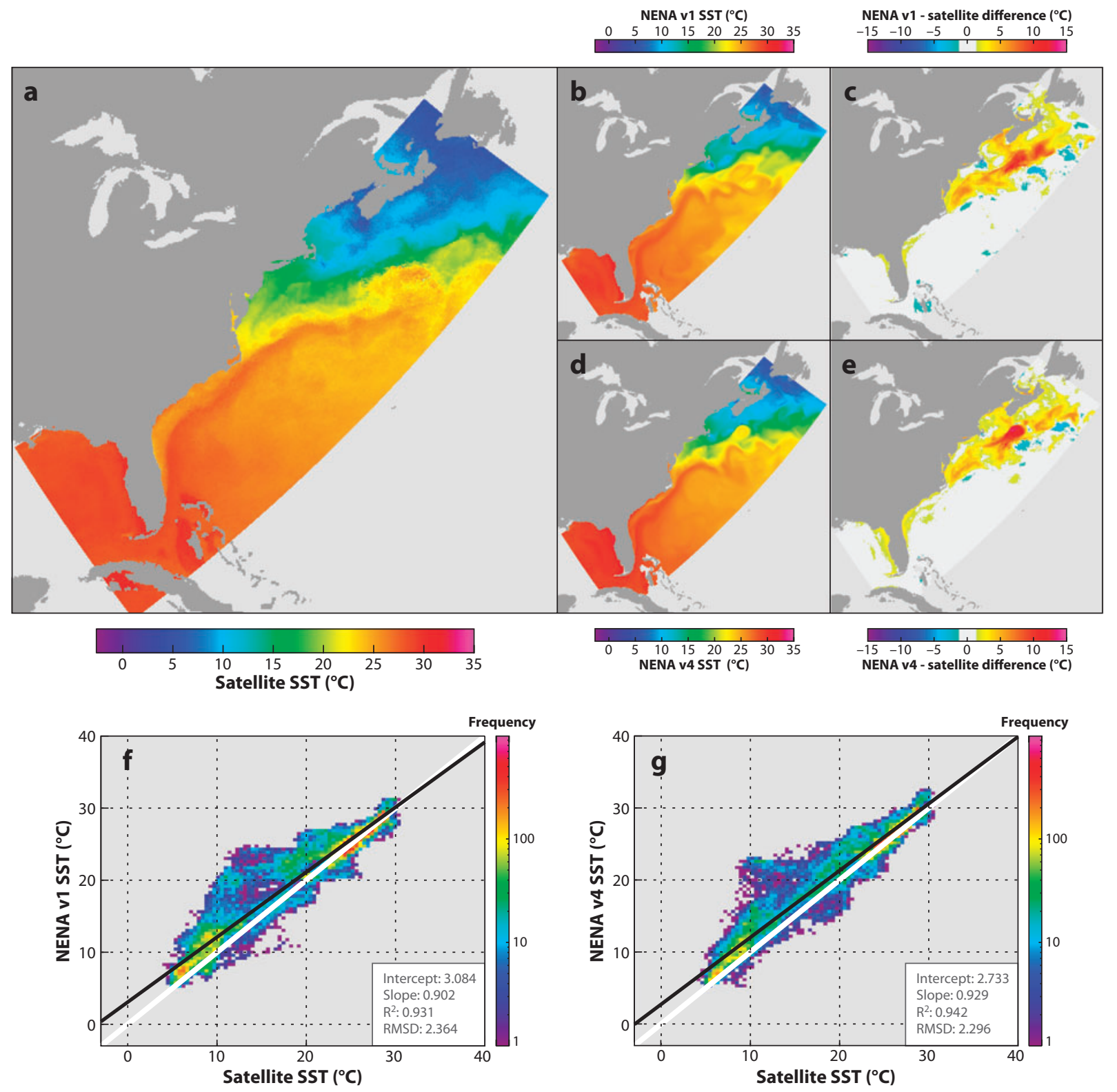

Figure 5

Comparison of monthly averaged satellite-derived sea surface temperature (SST) from June 2004 (a) with SST obtained from forcing with low-resolution fields (NENA v1; panel $b$ ) and higher-resolution fields (NENA v4; panel $d$ ). Monthly mean satellite SST data were derived from merged SST data from the AVHRR Pathfinder and MODIS (Terra and Aqua) sensors. Anomalies $(c, e)$ are represented as the difference between the modeled and satellite data, and the scatter plots are a joint probability distribution of the model results over the 40,013 satellite SST measurements. The region encompassed in the NENA model domain $(b-e)$ is the same region used for the June 2004 SST observations (a). Abbreviations: AVHRR, Advanced Very High Resolution Radiometer; MODIS, Moderate Resolution Imaging Spectroradiometer; NENA, northeastern North American model; RMSD, root mean squared difference. 

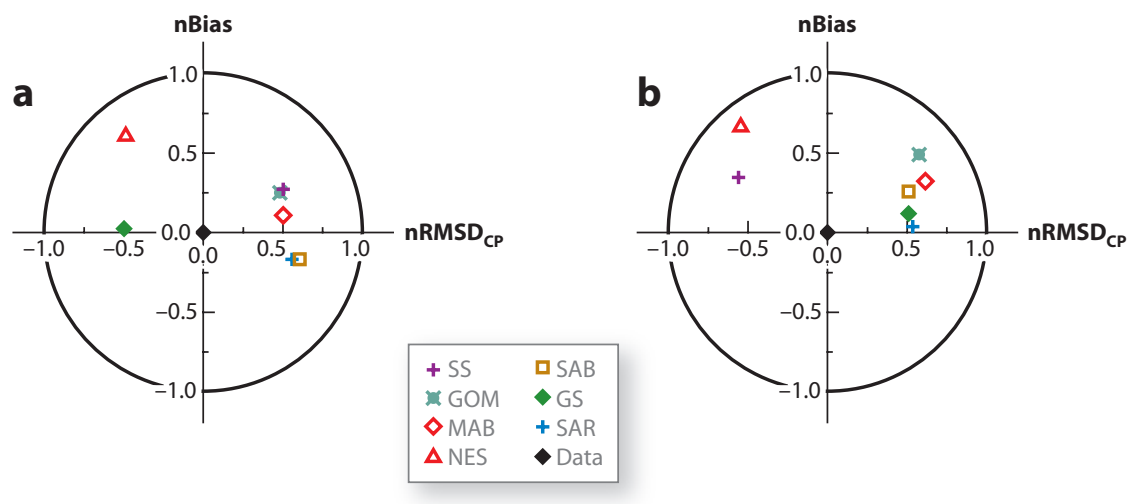

Figure 6

Target diagrams for time-series of monthly averaged modeled SST compared with satellite-derived SST for the simulation using (a) low-resolution forcing fields and that using $(b)$ higher-resolution forcing fields. The diagrams illustrate the normalized bias (nBias; $y$ axis), centered-pattern root mean squared difference (nRMSD ${ }_{\mathrm{CP}} ; x$ axis) and total RMSD (distance from the origin to each symbol). These statistics are normalized by the standard deviation of the observations and are shown for seven subregions of the model domain (defined in Figure 2): GOM, Gulf of Maine; GS, Gulf Stream; MAB, Middle Atlantic Bight; NES, Northeast Slope; SAB, South Atlantic Bight; SAR, Sargasso Sea; SS, Scotian Shelf.

\section{DATA RELIABILITY FOR MODEL EVALUATION}

Monthly, seasonal, and annually averaged vertical distributions of quantities, such as nutrients and chlorophyll, can be constructed from data archives, such as the World Ocean Atlas Data, but these are limited in spatial extent and represent climatological distributions, which provide guidance only on general structures and magnitudes.

Chlorophyll distributions derived from satellite ocean-color measurements are routinely used to evaluate the accuracy and skill of simulated chlorophyll fields. In most of these comparisons, the satellite-derived distributions are assumed to represent the truth, and statistical measures of the correspondences between the two fields are calculated to provide a quantitative measure of performance. Evaluation of the NENA model output has relied extensively on ocean color measurements (e.g., Figure 7a) and on quantities derived from these, such as primary production and POC. The satellite-derived data sets provide the best comparisons for the model-derived distributions because these data are on space and time scales that are compatible with those of the NENA model.

The Sea-viewing Wide Field-of-view Sensor (SeaWiFS) global algorithm used to construct chlorophyll distributions assumes the same characteristics for coastal, regional, open ocean, and basin scale environments. However, algorithms vary at regional scales and differ for coastal and open ocean environments (e.g., O’Reilly et al. 1998, Kahru \& Mitchell 2001, Stramska et al. 2003, Gregg \& Casey 2004, Darecki \& Stramski 2004, Stramska \& Stramski 2005). For example, the chlorophyll concentrations estimated for MAB coastal waters using the SeaWiFS algorithm are nearly a factor of two higher than those derived using an algorithm developed for this region (Pan et al. 2010) (Figure 8). Thus, model-data comparisons for the MAB shelf region that are based on SeaWiFS chlorophyll derived from the global algorithm may already have a bias that results from the way the data are analyzed.

In model-data evaluation exercises, it cannot be assumed a priori that the data represent the true state of the system. For data such as ocean color, construction of climatologies will allow 

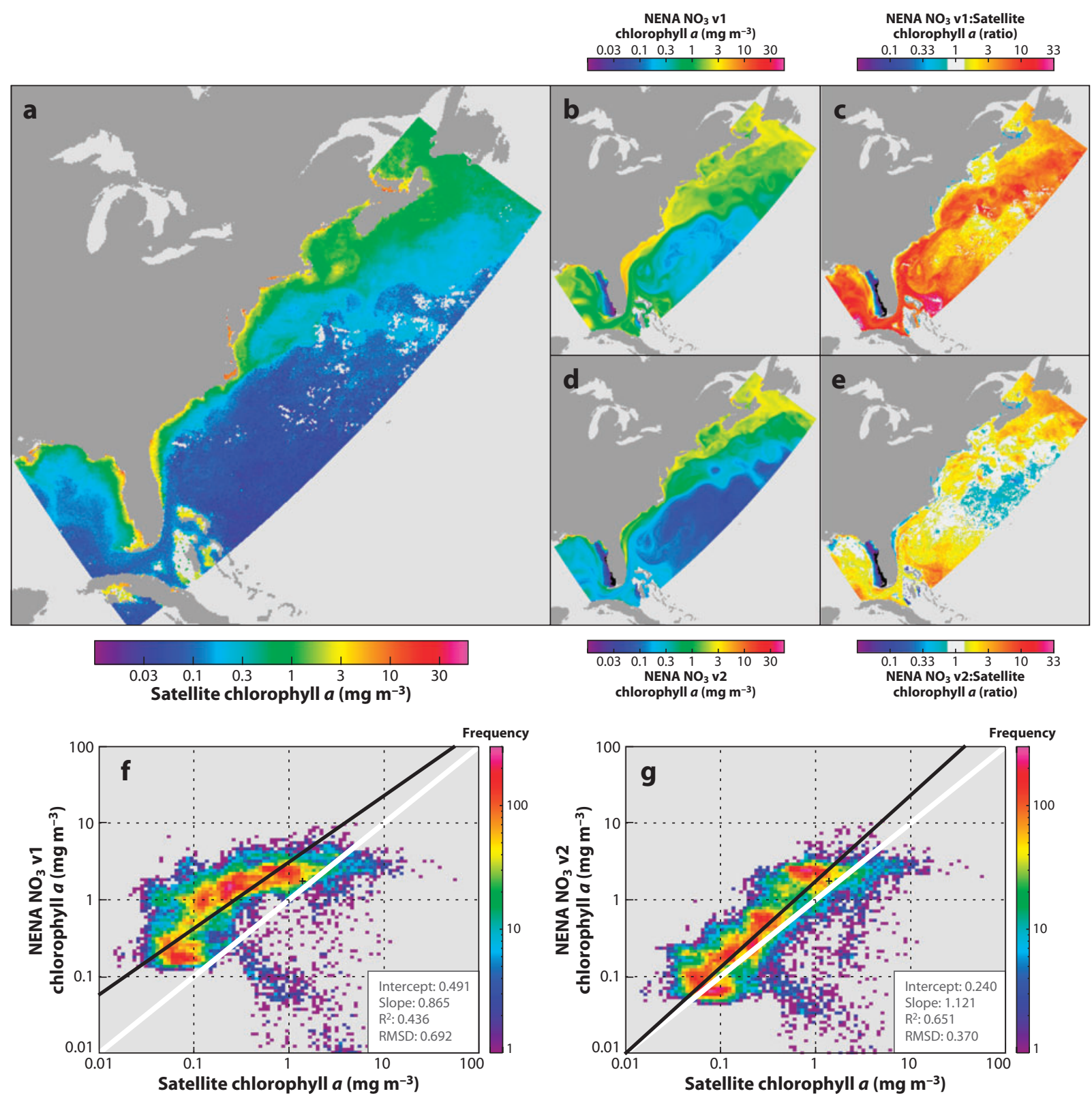

Figure 7

Comparison of monthly averaged chlorophyll values derived from Sea-Viewing Wide Field-of-view Sensor (SeaWiFS) ocean color measurements from October 2004 ( $a$ ) with simulated values obtained using original nitrate initial conditions (NENA v1; panel $b$ ) and updated nitrate initial conditions that include a better representation of along- and across-shelf gradients (NENA v2; panel $d$ ).

Anomalies $(c, e)$ are represented as ratios (model:satellite) because chlorophyll $a$ concentration is log-normally distributed. The scatter plots $(f, g)$ represent a joint probability distribution of the model results compared with the 36,800 satellite chlorophyll $a$ data points. Abbreviations: NENA, northeastern North American model; RMSD, root mean squared difference. 


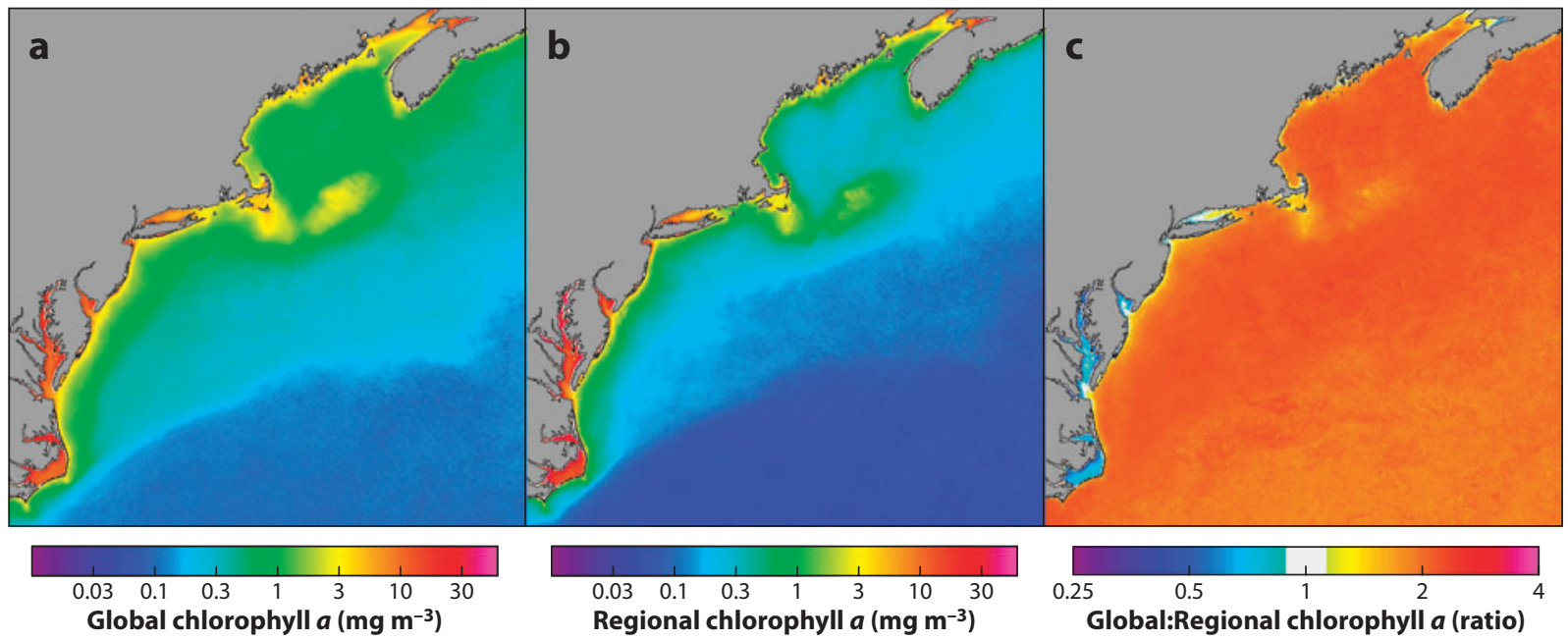

Figure 8

Comparison of chlorophyll concentrations and distributions obtained using (a) the standard Sea-Viewing Wide Field-of-view Sensor (SeaWiFS) global chlorophyll algorithm OC4 and $(b)$ a regional chlorophyll algorithm developed from measurements made in Middle Atlantic Bight coastal waters (Pan et al. 2010). (c) The ratio of the chlorophyll concentrations estimated by the two algorithms indicates that the global algorithm overestimates chlorophyll in coastal waters. These comparisons use 2004 annual mean SeaWiFS-derived chlorophyll distributions.

comparison of patterns, and the trends and relative changes obtained from these are likely correct. However, comparisons of absolute amplitudes and concentrations are not necessarily good metrics for evaluation of model accuracy and skill, because these depend on the level of uncertainty of satellite global ocean algorithms as applied to specific regions of interest. Where uncertainty levels exceed an acceptable threshold, other alternatives should be considered. For example, ocean color measurements that can be used for evaluation of continental-shelf carbon models may be possible with development of regional algorithms that are then blended between regions and the open ocean.

\section{NENA MODEL RESULTS}

The NENA model described in the previous sections has been used to address questions about biogeochemical processes on continental shelves and how these influence carbon budgets. A first application of the model focused on understanding sediment denitrification as a nutrient sink on the MAB continental shelf(Fennel et al. 2006). This modeling study was motivated by observations (Nixon et al. 1976, Aller 1980) that showed that only a fraction of the nitrogen associated with organic matter reaching the bottom in shelf environments was returned to the water column, whereas a significant fraction is denitrified in the sediments and thus lost from the system as nitrogen gas. Benthic mineralization processes are represented in the NENA model through a bottom boundary condition that balances the flux of organic matter sinking to the seafloor with an influx of inorganic nutrients at the sediment-water interface (Figure 3). The mean annual denitrification flux for the MAB calculated from the NENA simulations was $1.1 \mathrm{mmol} \mathrm{N} \mathrm{m}^{-2} \mathrm{~d}^{-1}$, which compared well with the fluxes estimated from observations $\left(1.4 \mathrm{mmol} \mathrm{N} \mathrm{m}^{-2} \mathrm{~d}^{-1}\right)$ for the eastern U.S. continental shelf region between Nova Scotia and Cape Hatteras (Seitzinger \& Giblin 1996) and with direct measurements of sediment denitrification $\left(1.7 \pm 0.6 \mathrm{mmol} \mathrm{N} \mathrm{m}^{-2} \mathrm{~d}^{-1}\right)$ 
at a site on the inner MAB shelf (Laursen \& Seitzinger 2002). A strength of the NENA model is that it allows development of synthesis products such as budgets; this approach was used to show the importance of sediment denitrification on the MAB (see Figure $\mathbf{8}$ in Fennel et al. 2006). Sediment denitrification was found to remove $90 \%$ of all of the nitrogen entering the MAB and is therefore an important process in determining the availability of fixed nitrogen and the primary production on the shelf. Extension of the MAB nitrogen flux estimated to the North Atlantic basin suggested that shelf denitrification could result in an annual removal of $2.3 \times$ $10^{12} \mathrm{~mol} \mathrm{~N}$, which is an order of magnitude greater than removal estimates by nitrogen fixation. A nitrogen sink on the continental shelf has direct implications for carbon cycling because the two are linked (Figures 2, 4). It was hypothesized that a denitrification flux should result in outgassing of $\mathrm{CO}_{2}$.

In a follow-up study, Fennel et al. (2008) illustrated the importance of linkages and feedbacks in nitrogen and carbon cycling dynamics using model-based studies of the effects of changes in nutrient availability and alkalinity due to sediment denitrification on the air-sea flux of $\mathrm{CO}_{2}$ in the MAB. This study combined the biological model used by Fennel et al. (2006) with a model that provided explicit representation of the inorganic carbon chemistry dynamics and air-sea gas exchange of $\mathrm{CO}_{2}$, which allowed testing of their 2006 hypothesis that nutrient removal by sediment denitrification will reduce the air-sea flux of $\mathrm{CO}_{2}$. The model was also used to do sensitivity studies designed to identify the controlling process for linking sediment denitrification and air-sea $\mathrm{CO}_{2}$ exchange. The simulations showed that decreased availability of fixed nitrogen due to denitrification reduces primary production and incorporation of inorganic carbon into organic matter. This produces an increase in seawater $p \mathrm{CO}_{2}$ and increases alkalinity, which in turn provides an opposing decrease in seawater $p \mathrm{CO}_{2}$. The air-sea $\mathrm{CO}_{2}$ flux estimated for the MAB from the NENA simulations is at the low end of those made for other continental shelf regions from modeling studies (Table 2).

Once $\mathrm{CO}_{2}$ is taken up from the atmosphere by the coastal oceans, its ultimate fate is determined by the magnitude of the processes that constitute the biological continental shelf carbon pump. Modeling studies have been used to estimate the amount of this carbon that is buried and/or exported from the continental shelf (Tables 1 and 2). The NENA model was used to estimate the portion of atmospheric $\mathrm{CO}_{2}$ taken up through biological processes on the MAB continental shelf and the portion that is exported from the shelf to the open ocean-quantities that are very difficult to obtain from direct measurements. The NENA simulations suggest that the annual areanormalized uptake of atmospheric $\mathrm{CO}_{2}$ over the $\mathrm{MAB}$ (Table 2) was not consistently larger than that in the adjacent deep ocean (Fennel \& Wilkin 2009). The horizontal export of carbon from the shelf was not sufficient to produce a significant continental shelf carbon pump for the North American eastern margin. Simulated $\mathrm{CO}_{2}$ uptake was maximal on the shelf during winter and spring, but simulated outgassing was maximal in summer and fall, which resulted in net annual fluxes that were similar to the adjacent open ocean region (Fennel \& Wilkin 2009). However, analysis of the simulations showed that the processes that produce the carbon export differ for the shelf and open ocean.

Inclusion of DOM dynamics in the NENA model (Druon et al. 2010) allowed further refinement of the carbon export processes from the MAB (Table 2). These simulations showed the importance of the large organic carbon pool represented by DOM in regulating MAB primary production. DOM also partially decouples the carbon and nitrogen cycles through its effects on carbon excess uptake, POM solubilization, and DOM mineralization. The inclusion of DOM increased the simulated primary production of the MAB by $60-180 \mathrm{~g} \mathrm{C} \mathrm{m}^{-2} \mathrm{y}^{-1}$ through increased ammonium release from DON mineralization in the upper water column and by excess production 
Table 4 Major carbon fluxes calculated from the northeastern North American simulations used in Fennel et al. (2008) ${ }^{\mathrm{a}}$

\begin{tabular}{|c|c|c|c|c|c|}
\hline Region & $\begin{array}{c}\mathrm{DIC}+\mathrm{POC} \\
\text { from rivers } \\
\left(10^{12} \mathrm{~g} \mathrm{C} \mathrm{y}^{-1}\right)\end{array}$ & $\begin{array}{c}\text { PP } \\
\left(10^{12} \mathrm{~g} \mathrm{C} \mathrm{y}^{-1}\right)\end{array}$ & $\begin{array}{c}\text { Total air-sea } \mathrm{CO}_{2} \\
\text { flux } \\
\left(10^{12} \mathrm{~g} \mathrm{C} \mathrm{y}^{-1}\right)\end{array}$ & $\begin{array}{c}\text { Horizontal } \\
\text { divergence of POC } \\
\left(10^{12} \mathrm{~g} \mathrm{C} \mathrm{y}^{-1}\right)\end{array}$ & $\begin{array}{c}\text { Horizontal divergence } \\
\text { of DIC } \\
\left(10^{12} \mathrm{~g} \mathrm{C} \mathrm{y}^{-1}\right)\end{array}$ \\
\hline Scotian Shelf & 0 & $13.8(0.0)$ & $3.8(-0.7)$ & $0.8(0.0)$ & $-1.1(+2.3)$ \\
\hline Gulf of Maine & 0.6 & $36.0(-7.0)$ & $3.6(+1.8)$ & $1.1(-0.4)$ & $14.1(-8.0)$ \\
\hline $\begin{array}{l}\text { Middle Atlantic } \\
\text { Bight }\end{array}$ & 1.6 & $21.8(-3.4)$ & $0.9(+0.5)$ & $0.5(+0.1)$ & $4.4(-3.5)$ \\
\hline $\begin{array}{l}\text { South Atlantic } \\
\text { Bight }\end{array}$ & 0.8 & $7.5(+11.9)$ & $-0.3(+1.0)$ & $0.5(+2.6)$ & $6.7(-1.2)$ \\
\hline
\end{tabular}

${ }^{a}$ The difference between these fluxes and those obtained from the NENAv4 simulations is shown in parentheses (NENAv4; Fennel et al. 2008). The flux differences illustrate the effect of changing a suite of factors (e.g., light parameterization, meteorological forcing, and new nitrate initial conditions) on carbon flux estimates. The fluxes were calculated for the model regions shown in Figure 2.

Abbreviations: DIC, dissolved inorganic carbon; POC, particulate organic carbon; PP, primary production.

of carbohydrates. Thus, addition of explicit DOM allowed a more complete description of carbon and nitrogen cycling on the MAB.

However, as discussed previously, fluxes estimated from the NENA model simulations (or any model) are dependent on choices made for initial conditions, parameterization of processes, and model dynamics (Figures 5-8). As an illustration of the effects of these choices, primary carbon fluxes were calculated from the NENA model used in Fennel et al. (2008) and a version that used higher-resolution forcing fields, revised initial nutrient conditions, and a different parameterization for light (NENAv4) (Figures 5, 7) but kept the circulation model resolution and the fundamental biogeochemical model unchanged. Any differences therefore stem from justifiable choices in the respective configurations and represent one realization of the uncertainty in the modeled flux estimates. Comparison of the differences in the estimated fluxes (Table 4) shows changes that are generally less than $20 \%$, except in the SAB where differences were much larger.

Model-derived carbon flux estimates, such as those provided in Table 4, and results from focused model-based research applications (Table 2) allow quantification of processes that control carbon cycling on continental shelves. Models are likely to be the only viable approach for inferring the many fluxes that control carbon cycling on continental shelves (Figure 4) in a consistent manner. However, the fluxes derived from models have an associated uncertainty that is based in choices made in model development and implementation.

\section{CHALLENGES AND THE FUTURE}

The scale of application of a model places important limitations that have implications for the model results. Models for continental shelf systems are perhaps the most difficult to develop because global, estuarine, and regional scales come together at the scale of continental shelf systems. The previous sections clearly show that model solutions are dependent on choices made for implementation approaches and parameterizations that arise because of the scales that are addressed by the model. Boundary conditions, initial conditions, and forcing fields provide information at scales larger than those resolved by the model, and how these are prescribed has significant effects on the skill of the model simulations. For the NENA model, the high-resolution forcing fields used for air temperature and downwelling radiation improved simulation of SST, and changing the initial condition formulation for nitrate improved the simulation of surface chlorophyll. However, improvement in one model component may remove problems that mask 
incorrect dynamics in other components that were not apparent in the solutions. Incremental changes in model structure and reevaluation of model skill is an ongoing, iterative process that is critical to the development of carbon cycle models. Hindcasts with accompanying rigorous analysis of model solutions provide a powerful approach for model improvement.

The NENA model is one of several developed for continental shelf systems (Table 2). The models vary in their dynamics, but all provide estimates of primary production, which allows acrosssystem comparisons. Analysis of differences in these estimates provides a basis for understanding what drives carbon cycling in a wide range of systems. The earlier versions of the NENA model included less complex biological dynamics than other models, but they allowed for coupling at all the land, ocean, and atmosphere boundaries as well as explicit representation of carbon and nutrient cycling.

For the NENA model and other coastal carbon models, benthic-pelagic coupling is important for internal carbon and nutrient transformations. The current configuration of NENA parameterizes benthic-pelagic coupling in terms of a bottom boundary flux (Figure 3). However, the apparent importance of sediment denitrification processes in continental shelf systems (Fennel et al. 2009), for example, underscores the need for explicit representation of these processes in continental-shelf carbon models.

Improvement in simulation of phytoplankton distribution and production will require inclusion of more than one phytoplankton functional group. The single component used in Fennel et al. (2006, 2008) and Druon et al. (2010) is adequate for simulation of general patterns and trends. However, matching simulated and observed distributions and projecting future changes requires more flexibility in the trophic level that is controlling primary production. Expansion of the primary production component of the NENA model may also require better representations of coastal optics and aggregation and sedimentation effects. These processes are now in the NENA model but are parameterized using general formulations based on measurements from a range of environments. The regional specificity of these processes is unknown and thus represents an area where research can inform and improve continental-shelf carbon models.

Specification of boundary conditions for regional continental shelf models requires details for the land-ocean, ocean-atmosphere, and sediment-water boundaries. The NENA model uses a range of approaches, models, and data sets to specify inputs at these boundaries. The choices used for specifying the boundaries are determined by what is available rather than by what is needed. Throughout development of the NENA model, much effort has gone into representing processes on boundaries because these have proved to have important effects on the model-derived distributions. A lesson learned from the NENA model is that linking of different models (e.g., HYCOM) is not straightforward, because biases and trends in the solutions of one model are transferred to the other model. The resultant mismatch in model dynamics can overwhelm the simulations of the regional model. The ability to link different models is nevertheless critical, especially as emphasis is placed on long-term projection of future states.

The solutions obtained with the current configuration of the NENA model represent only a single realization of possible outcomes. Ensembles of solutions provide more robust estimates of carbon cycling on continental shelf systems because ensembles allow for the inclusion of uncertainty in model processes, and also in initial and boundary conditions. However, using an ensemble approach requires information to specify ranges for processes, which in turn requires more extensive data sets that describe processes of carbon and nitrogen cycling. This approach also places a greater demand on computing resources.

Quantitative evaluation of simulations is a critical and required component of any model application (e.g., Hofmann et al. 2008). However, the quality and uncertainty of the data sets used for this evaluation need to be assessed. The comparison between chlorophyll fields obtained with the 
SeaWiFS global and regional algorithms underscores the problems with comparisons against a data set that is considered the standard for model evaluations. Similar issues arise when comparing model solutions obtained using forcing conditions for a particular time and/or location against data climatologies. Much still needs to be done to determine the best approaches for modeldata comparisons that will reveal fundamental issues with models that are not the result of data structure.

Equally important are analyses of model structure, model complexity, and model uncertainty. Such analyses are needed to determine both the benefits accrued by including additional components versus using a more accurate representation of rates and processes and the implications of these for reducing model uncertainty. Variational data assimilation techniques provide an approach for evaluating these issues (Friedrichs et al. 2006, 2007). Improved projections of carbon cycling on continental shelf systems may be best obtained via data assimilation techniques combined with mechanistic approaches. However, there are trade-offs in this approach that come from the amount and type of data that are needed and the computational resources needed for parameter estimation.

Removal of biomass via fisheries, changes in freshwater inputs and wind patterns due to climate change, and increasing coastal hypoxia are just a few examples of effects that will potentially alter carbon and nitrogen cycling on continental shelves. As these natural and human-induced changes continue, more emphasis will be placed on models to project the consequences of these actions for continental shelf systems. Models, such as the NENA model, can be used to address these issues. These models will continue to undergo development, and it is important to ensure that the products from these models, e.g., simulations of acidification and primary production trends, are available in a form that can be used by policy and management communities.

\section{DISCLOSURE STATEMENT}

The authors are not aware of any affiliations, memberships, funding, or financial holdings that might be perceived as affecting the objectivity of this review.

\section{ACKNOWLEDGMENTS}

The U.S. Eastern Continental Shelf project is supported by the National Aeronautics and Space Administration (NASA) Interdisciplinary Science Program (NASA Award NNG04GL68G) and by the NASA Carbon Cycle Science through the Ocean Biology and Biogeochemistry Program (NASA award NNX08AO25G). The SeaWiFS and MODIS ocean color data were obtained from the NASA Ocean Biology Processing Group (http://oceancolor.gsfc.nasa.gov). The sea surface temperature data were derived from nighttime scenes composited from the AVHRR Pathfinder sensor on the National Oceanic and Atmospheric Administration's polarorbiting satellites (http://podaac.jpl.nasa.gov) and from NASA's MODIS Terra and Aqua sensors (http://oceancolor.gsfc.nasa.gov).

\section{LITERATURE CITED}

Allen JI, Blackford J, Holt J, Proctor R, Ashworth M, Siddom J. 2001. A highly spatially resolved ecosystem model for the North West European Continental Shelf. Sarsia 86:423-40

Aller RC. 1980. Diagenetic processes near the sediment-water interface of Long Island Sound. I. Decompositoin and nutrient element chemistry (S, N, P). Adv. Geophys. 22:238-50 
Aller RC. 1988. Benthic fauna and biogeochemical processes in marine sediments: the role of burrow structures. In Nitrogen Cycling in Coastal Marine Environments, ed. THS Blackburn, J Sorensen, pp. 301-38. Chichester, UK: Wiley

Aller RC. 1994. Bioturbation and remineralization of sedimentary organic matter: effects of redox oscillation. Chem. Geol. 114:331-45

Álvarez-Salgado XA, Gago J, Míguez BM, Pérez FF. 2001. Net ecosystem production of dissolved organic carbon in a coastal upwelling system: the Ría de Vigo, Iberian margin of the North Atlantic. Limnol. Oceanogr. 46:135-47

Arrigo KR, van Dijken G, Long M. 2008. Coastal Southern Ocean: a strong anthropogenic $\mathrm{CO}_{2}$ sink. Geophys. Res. Lett. 35:L21602

Borges AV, Delille B, Frankignoulle M. 2005. Budgeting sinks and sources of $\mathrm{CO}_{2}$ in the coastal ocean: diversity of ecosystems counts. Geophys. Res. Lett. 32:L14601

Cahill B, Schofield O, Chant R, Wilkin J, Hunter E, et al. 2008. Dynamics of turbid buoyant plumes and the feedbacks on near-shore biogeochemistry and physics. Geophys. Res. Lett. 35:L10605

Cai W-J. 2011. $\mathrm{CO}_{2}$ flux and net heterotrophy in coastal waters. Annu. Rev. Mar. Sci. 3: In press

Cai W-J, Dai M, Wang Y. 2006. Air-sea exchange of carbon dioxide in ocean margins: a province-based sysnthesis. Geophys. Res. Lett. 33:L12603

Cai W-J, Wang Y, Hodson RE. 1998. Acid-base properties of dissolved organic matter in the estuarine waters of Georgia, US. Geochim. Cosmochim. Acta 62:473-83

Cai W-J, Wang Z, Wang Y. 2003. The role of marsh-dominated heterotrophic continental margins in transport of $\mathrm{CO}_{2}$ between the atmosphere, the land-sea interface and the ocean. Geophys. Res. Lett. 30:1849

Calbet A, Landry MR. 2004. Phytoplankton growth, microzooplankton grazing, and carbon cycling in marine systems. Limnol. Oceanogr. 49:51-57

Chai F, Liu G, Xue H, Shi L, Chao Y, et al. 2009. Seasonal and interannual variability of carbon cycle in South China Sea: a three-dimensional physical-biogeochemical modeling study. F. Oceanogr. 65:703-20

Chassignet EP, Hurlbert HE, Smedstad OM, Halliwell GR, Hogan PJ, et al. 2007. The HYCOM (HYbrid Coordinate Ocean Model) data assimilative system. 7. Mar. Sys. 65:60-83

Chen CTA. 2002. Shelf-vs. dissolution-generated alkalinity above the chemical lysocline. Deep-Sea Res. II. 49:5365-375

Conkright ME, Locarnini RA, Garcia HE, O'Brien TD, Boyer TP, et al. 2002. World Ocean Atlas 2001: objective analyses, data statistics and figures CD-ROM documentation. National Oceanographic Data Center Internal Report, 17. US Dept. Commer.: Silver Spring, MD. 17 pp.

Cook T, Folli M, KlinckJ, Ford S, Miller J. 1998. The relationship between increasing sea-surface temperature and the northward spread of Perkinsus marinus (Dermo) disease epizootics in oysters. Estuar. Coast. Shelf Sci. 46:587-97

Cornell SE, Jickells TD, Cape JN, Rowland AP, Duce RA. 2003. Organic nitrogen deposition on land and coastal environments: a review of methods and data. Atmos. Environ. 37:2173-91

Dagg M, Benner R, Lohrenz S, Lawrence D. 2004. Transformation of dissolved and particulate materials on continental shelves influenced by large rivers: plume processes. Cont. Shelf Res. 24:833-58

Darecki M, Stramski D. 2004. An evaluation of MODIS and SeaWiFS bio-optical algorithms in the Baltic Sea. Remote Sens. Environ. 89:326-350

D'Asaro E, McNeil C. 2007. Air-sea gas exchange at extreme wind speeds measured by autonomous oceanographic floats. F. Mar. Sys. 66:92-109

DeGrandpre MD, Olbu GJ, Beatty CM, et al. 2002. Air-sea $\mathrm{CO}_{2}$ fluxes on the US Middle Atlantic Bight. Deep-Sea Res. II 49:4355-67

Diaz RJ, Rosenberg R. 2008. Spreading dead zones and consequences for marine ecosystems. Science 321:92629

Dinniman MS, Klinck JM, Smith WO Jr. 2003. Cross-shelf exchange in a model of the Ross Sea circulation and biogeochemisty. Deep-Sea Res. II 50:3103-120

Doney SC, Mahowald N, Lima I, Feely RA, Mackenzie FT, et al. 2007. Impact of anthropogenic atmospheric nitrogen and sulfur deposition on ocean acidification and the inorganic carbon system. Proc. Natl. Acad. Sci. USA 104:14580 
Donner SD, Coe M, Lenters JD, Twine TE, Foley JA. 2002. Modeling the impact of hydrological changes on nitrate transport in the Mississippi River Basin from 1955 to 1994. Glob. Biogeochem. Cycles 16:GB001396

Druon J, Mannino A, Signorini S, McClain M, Friedrichs M, Wilkin J, et al. 2010. Modeling the dynamics and export of dissolved organic matter in the Northeastern U.S. continental shelf. Estuar. Coast. Shelf Sci. 88:488-507

Duce RA, LaRoche J, Altieri K, Arrigo KR, Baker AR, et al. 2008. Impacts of atmospheric anthropogenic nitrogen on the open ocean. Science 320:893-97

Ducklow HW, McAllister SL. 2005. The biogeochemistry of carbon dioxide in the coastal oceans. In The Sea, ed. AR Robinson, KH Brink, vol. 13, pp. 269-315. Cambridge, MA: Harvard Univ. Press

Dumont E, Harrison J, Kroeze C, Bakker E, Seitzinger S. 2005. Global distribution and sources of dissolved inorganic nitrogen export to the coastal zone: results from a spatially explicit, global model. Glob. Biogeochem. Cycles 19:GB4S02.

Egbert GD, Erofeeva SY. 2002. Efficient inverse modeling of barotropic ocean tides. F. Atmos. Ocean. Tech. 19:183-204

Fairall CW, Bradley EF, Hare JE, Grachev AA, Edson J. 2003. Bulk parameterization of air-sea fluxes: updates and verification for the COARE algorithm. F. Clim. 16:571-91

Fennel K, Brady D, DiToro D, Fulweiler R, Gardner WS, et al. 2009. Modelling denitrification in aquatic sediments. Biogeochemistry 93:159-78

Fennel K, Wilkin J. 2009. Quantifying biological carbon export for the northwest North Atlantic continental shelves. Geophys. Res. Lett. 36:L18605

Fennel K, Wilkin J, Levin J, Moisan J, O'Reilly J, et al. 2006. Nitrogen cycling in the middle atlantic bight: results from a three-dimensional model and implications for the North Atlantic nitrogen budget. Glob. Biogeochem. Cycles 20:GB3007

Fennel K, Wilkin J, Previdi M, Najjar R. 2008. Denitrification effects on air-sea $\mathrm{CO}_{2}$ flux in the coastal ocean: Simulations for the northwest North Atlantic. Geophys. Res. Lett. 35:L24608

Flather RA. 1976. A tidal model of the northwest European continental shelf. Memoirs Societe Royale Sciences Liège Series 6:141-64

Frankignoulle M, Borges AV. 2001. European continental shelf as a significant sink for atmospheric carbon dioxide. Glob. Biogeochem. Cycles 15:569-76

Frew NM, Nelson RK, Mcgillis WR, Edson JB, Bock EJ, Hara T. 2002. Spatial variations in surface microlayer surfactants and their role in modulating air-sea exchange, pp. 153-159. In Gas Transfer at Water Surfaces, Geophys. Monogr. Ser. 127, ed. MA Donelan, WM Drennan, ES Saltzman, R Wanninkhof. Washington, DC: Am. Geophys. Union

Friedrichs MAM, Dusenberry J, Anderson L, Armstrong R, Chai F, Christian J, et al. 2007. Assessment of skill and portability in regional marine biogeochemical models: role of multiple phytoplankton groups. 7. Geophys. Res. 112:CO8001

Friedrichs MAM, Hood RR, Wiggert JD. 2006. Ecosystem model complexity versus physical forcing: quantification of their relative impact with assimilated Arabian Sea data. Deep-Sea Res. II 53:576-600

Gattuso J-P, Frankignoulle M, Wollast R. 1998. Carbon and carbonate metabolism in coastal aquatic ecosystems. Annu. Rev. Ecol. Syst. 29:405-34

Gregg WG, Casey NW. 2004. Global and regional evaluation of the SeaWiFS chlorphyll data set. Remote Sens. Environ. 93:463-79

Gruber N, Frenzel H, Doney SC, Marchesiello P, McWilliams JC, et al. 2006. Eddy-resolving simulation of plankton ecosystem dynamics in the California Current system. Deep-Sea Res. II 53:1483-516

Guerzoni S, Chester R, Dulac F, Herut B, Loÿe-Pilot MD, et al. 1999. The role of atmospheric deposition in the biogeochemistry of the Mediterranean Sea. Prog. Oceanogr. 44:147-90

Hagy JD, Boynton WR, Keefe CW, Wood KV. 2004. Hypoxia in Chesapeake Bay, 1950-2001: long-term change in relation to nutrient loading and river flow. Estuar. Coasts 27: doi:10.1007/BF02907650

Hansell DA, Carlson CA. 1998. Net community production of dissolved organic carbon. Glob. Biogeochem. Cycles 12:443-53

Hartnett HE, Keil RG, Hedges JI, Devol AH. 1998. Influence of oxygen exposure time on organic carbon preservation in continental margin sediments. Nature 391:572-74 
Henrichs S, Reeburgh W. 1987. Anaerobic mineralization of marine sediment organic matter: rates and the role of anaerobic processes in the oceanic carbon economy. Geomicrobiol. 7. 5:1-237

Hernandez-Ayon JM, Zirino A, Dickson AG, Camiro-Vargas T, Valenzuela E. 2007. Estimating the contribution of organic bases from microalgae to the titration alkalinity in coastal seawaters. Limnol. Oceanogr. Methods 5:225-32

Hofmann E, Druon J-N, Fennel K, Friedrichs M, Haidvoge D, et al. 2008. Eastern US continental shelf carbon budget: integrating models, data assimilation and analysis. Oceanography 21:32-40

Honjo S, Manganini SJ, Krishfield RA, Francois R. 2008. Particulate organic carbon fluxes to the ocean interior and factors controlling the biological pump: a synthesis of global sediment trap programs since 1983. Prog. Oceanogr. 76:217-85

Hood RR, Laws EA, Armstrong RA, Bates RR, Brown CW, Carlson CC, et al. 2006. Pelagic functional group modeling: progress, challenges and prospects. Deep-Sea Res. II 53:459-512

Hopkinson CS Jr, Vallino JJ, Nolin A. 2002. Decomposition of dissolved organic matter from the continental margin. Deep-Sea Res. II 49:4461-78

Howarth RW, Billen G, Swaney D, Townsend A, Jaworski N, et al. 1996. Regional nitrogen budgets and riverine $\mathrm{N}$ and $\mathrm{P}$ fluxes for the drainages to the North Atlantic Ocean: natural and human influences. Biogeochemistry 35:75-139

Huettel M, Ziebis W, Forster S. 1996. Flow-induced uptake of particulate matter in permeable sediments. Limnol. Oceanogr. 41:309-22

Huettel M, Ziebis W, Forster S, Luther GW. 1998. Advective transport affecting metal and nutrient distributions and interfacial fluxes in permeable sediments. Geochim. Cosmochim. Acta 62:613-31

Ianson D, Allen SE. 2002. A two-dimensional nitrogen and carbon flux model in a coastal upwelling region. Glob. Biogeochem. Cycles 16: doi:10.1029/2001GB001451

Jahnke RA. 2010. Global synthesis. See Liu K-K, Atkinson L, Quiñones R, Talaue-NcManus L, 2010, pp. 597615

Jiang L-Q, Cai W-J, Wanninkhof R, Wang Y, Lüger H. 2008. Air-sea CO 2 fluxes on the U.S. South Atlantic Bight: spatial and seasonal variability. 7. Geophys. Res. 113:C07019

Jickells T. 2006. The role of air-sea exchange in the marine nitrogen cycle. Biogeosci. Disc. 3:183-210

JoliffJ, Kindle JC, Shulman I, Penta B, Friedrichs MAM, Helber R, et al. 2009. Summary diagrams for coupled hydrodynamic-ecosystem model skill assessment. 7. Mar. Syst. 76:64-82

Kahru M, Mitchell BG. 2001. Seasonal and nonseasonal variaiblity of satellite-derived chlorophyll and colored dissolved organic matter concentration in the Califronia Current. 7. Geophys. Res. 106:2517-529

Keene WC, Montag JA, Maben JR, Southwell M, Leonard J, Church TM, et al. 2000. Organic nitrogen in precipitation over Eastern North America. Atmos. Environ. 36:4529-540

Keil RG, Mayer LM, Quay PD, Richey JE, Hedges JI. 1997. Loss of organic matter from riverine particles in deltas. Geochim. Cosmochim. Acta 61:1507-11

Kim HC, Lee K, Choi W. 2006. Contribution of phytoplankton and bacterial cells to the measured alkalinity of seawater. Limnol. Oceanogr. 51:331-38

Koeve W. 2001. Wintertime nutrients in the North Atlantic-new approaches and implications for new production estimates. Mar. Chem. 74:245-60

Komada T, Reimers CE. 2001. Resuspension-induced partitioning of organic carbon between solid and solution phases from a river-ocean transition. Mar. Chem. 176:155-74

Komada T, Schofield OME, Reimers CE. 2002. Fluorescence characteristics of organic matter released from coastal sediments during resuspension. Mar. Chem. 79:81-97

Krishnamurthy A, Moore JK, Zender CS, Chao L. 2007. Effects of atmospheric inorganic nitrogen deposition on ocean biogeochemistry. 7. Geophys. Res. 112:G02019

Kristensen E. 2000. Organic matter diagenesis at the oxic/anoxic interface in coastal marine sediments, with emphasis on the role of burrowing animals. Hydrobiologia 426:1-24

Kuypers MMM, Lavik G, Woebken D, Schmid M, Fuchs BM, et al. 2005. Massive nitrogen loss from the Benguela upwelling system through anaerobic ammonium oxidation. Proc. Natl. Acad. Sci. USA 102:647883

Laursen AE, Seitzinger SP. 2002. The role of denitrification in nitrogen removal and carbon mineralization in the Mid-Atlantic Bight sediments. Cont. Shelf Res. 22:1397-1416 
Lee K, Wanninkhof R, Feely RA, Millero FJ, Peng TH. 2000. Global relationships of total inorganic carbon with temperature and nitrate in surface seawater. Glob. Biogeochem. Cycles 14:979-94

Lehmann MK, Fennel K, He R. 2009. Statistical validation of a 3-D bio-physical model of the western North Atlantic. Biogeosciences 6:1-14

Le Quéré C, Harrison SP, Prentice IC, Buitenhuis ET, Aumont O, Bopp L, et al. 2005. Ecosystem dynamics based on plankton functional types for global ocean biogeochemistry models. Glob. Change Biol. 11:201640

Liss PS, Duce RA. 1997. The Sea Surface and Global Change. Cambridge, UK: Cambridge Univ. Press. 535 pp.

Liu G, Chai F. 2009. Seasonal and interannual variability of primary and export production in the South China Sea: a three-dimensional physical-biogeochemical model study. ICES 7. Mar. Sci. 66:420-31

Liu K-K, Atkinson L, Quiñones R, Talaue-NcManus L. 2010. Carbon and Nutrient Fluxes in Continental Margins: A Global Synthesis. Berlin: Springer. 741 pp.

Liu M, Tian H, Chen G, Ren W, Zhang C, et al. 2008. Effects of land use and land cover change on evapotranspiration and water yield in China during the twentieth century. 7. Am. Water Res. Assoc. 44:1193-207

Longhurst A. 1995. Seasonal cycles of pelagic production and consumption. Prog. Oceanogr. 36:77-167

Loye-Pilot MD, Martin JM, Morelli J. 1990. Atmospheric input of inorganic nitrogen to the western Mediterranean. Biogeochemistry 9:117-34

Lutjeharms JRE, Penven P, Roy C. 2003. Modelling the shear edge eddies of the southern Agulhas Current. Cont. Shelf Res. 23:1099-115

Mackenzie FT, Lerman A, Andersson AJ. 2004. Past and present of sediment and carbon biogeochemical cycling models. Biogeosciences 1:11-32

Marchesiello P, McWilliams JC, Shchepetkin AF. 2003. Equilibrium structure and dynamics of the California Current system. F. Phys. Oceanogr. 33:753-83

Marra J, Trees CC, O'Reilly JE. 2007. Phytoplankton pigment absorption: a strong predictor of primary productivity in the surface ocean. Deep-Sea Res. I 54:155-63

Mellor GL, Yamada T. 1982. Development of a turbulence closure model for geophysical fluid problems. Rev. Geophys. Space Phys. 20:851-75

Mesinger F, DiMego G, Kalnay E, Mitchell K, Shafran W, et al. 2006. North American regional reanalysis. Bull. Am. Meteorol. Soc. 87:343-60

Middelburg JJ, Soetaert K, Herman PMJ, Heip C. 1996. Denitrification in marine sediments: a model study. Glob. Biogeochem. Cycles 10:661-73

Millero FJ, Lee K, Roche M. 1998. Distribution of alkalinity in the surface waters of the major oceans. Mar. Chem. 60:111-30

Milliman J. 1993. Production and accumulation of calcium carbonate in the ocean: Budget of a nonsteady state. Glob. Biogeochem. Cycles 7:927-57

Moisan JR. 2010. Coupled circulation/biogeochemical models to estimate carbon flux. See K-K Liu, L Atkinson, R Quiñones, L Talaue-McManus, 2010, pp. 539-58

Moll A. 1998. Regional distribution of primary production in the North Sea simulated by a three-dimensional model. 7. Mar. Sys. 16:151-70

Moore WS. 2010. The effect of submarine groundwater discharge on the ocean. Annu. Rev. Mar. Sci. 2:59-88

Moore WS, Sarmiento JS, Key RM. 2008. Submarine groundwater discharge revealed by ${ }^{228}$ Ra distribution in the upper Atlantic Ocean. Nat. Geosci. 1:309-11

Mopper K, Kieber DJ. 2000. Marine photochemistry and its impact on carbon cycling. In The Effects of UV Radiation in the Marine Environment, ed. S De Mora, S Demer, M Vernet, pp. 101-129. Cambridge, UK: Cambridge Univ. Press

Muller-Karger FE, Varela R, Thunell R, Luerssen R. 2005. The importance of continental margins in the global carbon cycle. Geophys. Res. Lett. 32:L01602

Najjar RG, Pyke CR, Adams MB, Breitburg D, Hershner C, Kemp M, et al. 2010. Potential climate-change impacts on the Chesapeake Bay. Estuar. Coast. Shelf Sci. 86:1-20

Nightingale PD, Malin G, Law CS, Watson AJ, Liss PS, et al. 2000. In situ evaluation of air-sea gas exchange parameterizations using novel conservative and volatile tracers. Glob. Biogeochem. Cycles 14:373-87 
Nixon SW, Oviatt CA, Hale SS. 1976. Nitrogen regeneration and the metabolism of coastal marine bottom communities. In The Role of Terrestrial and Aquatic Organism Decomposition Processes, ed. JM Anderson, A Macfadyen, pp. 269-83. Malden, MA: Blackwell

Onitsuka G, Uno I, Yanagi T, Yoon JH. 2009. Modeling the effects of atmospheric nitrogen input on biological production in the Japan Sea. 7. Oceanogr. 65:433-38

O’Reilly JE, Maritorena S, Mitchell BG, Siegel DA, Carder KL, Garver SA, et al. 1998. Ocean color chlorophyll algorithms for SeaWiFS. F. Geophys. Res. 103:24937-53

Pace ML, Glasser JE, Pomeroy LR. 1984. A simulation analysis of continental shelf food webs. Mar. Biol. $82: 47-63$

Paerl HW, Dennis RL, Whitall DR. 2002. Atmospheric deposition of nitrogen: implications for nutrient overenrichment of coastal waters. Estuar. Coasts 25:677-93

Pan X, Mannino A, Russ ME, Hooker SB, Harding LW Jr. 2010. Remote sensing of phytoplankton pigment distribution in the United States Northeast coast. Remote Sens. Environ. 114:2403-16

Peliz A, Dubert J, Haidvogel DB. 2003. Subinertial response of a density-driven eastern boundary current poleward current to wind forcing. F. Phys. Oceanogr. 33:1633-1650

Pomeroy LR, D'Elia CF, Schaffner LC. 2006. Limits to top-down control of phytoplankton by oysters in Chesapeake Bay. Mar. Ecol. Prog. Ser. 325:301-9

Previdi M, Fennel K, Wilkin J, Haidvogel DB. 2009. Interannual variability in atmospheric $\mathrm{CO}_{2}$ uptake on the northeast U.S. continental shelf. 7. Geophy. Res. 114:G04003

Radach G, Moll A. 1993. Estimation of the variability of production by simulating annual cycles of phytoplankton in the central North Sea. Prog. Oceanogr. 31:339-419

Reimers CE, Stecher HA, Taghon GL, Fuller CM, Huettel M, et al. 2004. In situ measurements of advective solute transport in permeable shelf sands. Cont. Shelf Res. 24:183-201

Rhoads DC. 1974. Organism-sediment relations on the muddy sea floor. Oceanogr. Mar. Biol. Ann. Rev. $12: 263-300$

Sarmiento JL, Gruber N. 2006. Ocean Biogeochemical Dynamics. Princeton, NJ: Princeton Univ. Press. 503 pp.

Seitzinger SP, Giblin AE. 1996. Estimating denitrification in North Atlantic continental shelf sediments. Biogeochemistry 35:235-60

Seitzinger SP, Harrison JA, Böhlke JK, Bouwman AF, Lowrance R, et al. 2006. Denitrification across landscapes and waterscapes: a synthesis. Ecol. Appl. 16:2064-90

Shchepetkin AF, McWilliams JC. 1998. Quasi-monotone advection schemes based on explicit locally adaptive dissipation. Mon. Weather Rev. 126:1541-80

Shchepetkin AF, McWilliams JC. 2003. A method for computing horizontal pressure-gradient force in an oceanic model with a non-aligned vertical coordinate. 7. Geophys. Res. 108:C33090

Shchepetkin AF, McWilliams JC. 2005. The regional ocean modeling system (ROMS): a split-explicit, freesurface, topography-following-coordinate ocean model. Ocean Model. 9:347-404

Shuert PG, Walsh JJ. 1993. A coupled physical-biological model of the Bering-Chukchi seas. Cont. Shelf Res. 13:543-73

Slomp CP, Van Cappellen P. 2004. Nutrient inputs to the coastal ocean through submarine groundwater discharge: controls and potential impact. 7. Hydro. 295:64-86

Smith SV, Hollibaugh JT. 1993. Coastal metabolism and the oceanic organic carbon balance. Rev. Geophys. 31:75-89

Soetaert K, MiddelburgJJ, Herman PMJ, Buis K. 2000. On the coupling of benthic and pelagic biogeochemical models. Earth-Sci. Rev. 51:173-201

Spokes LJ, Yeatman SG, Cornell SE, Jickells TD. 2000. Nitrogen deposition to the eastern Atlantic Ocean. The importance of southeasterly flow. Tellus B 52:37-49

Stramska M, Stramski D, Hapter R, Kaczmarck S, Stoń J. 2003. Bio-optical relationships and ocean color algorithms for the north polar region of the Atlantic. F. Geophys. Res. 108:C53143

Stramska M, Stramski D. 2005. Variability of particulate organic carbon concentration in the north polar Atlantic based on ocean color observations with Sea-viewing Wide Field-of-view Sensor (SeaWiFS). 7. Geophys. Res. 110:C10018

Thomas H, Bozec Y, Elkalay K, de Barr HJW 2004. Enhanced open ocean storage of $\mathrm{CO}_{2}$ from shelf sea pumping. Science 304:1005-8 
Tian HQ, Xu X, Zhang C, Ren W, Chen G, et al. 2009. Forecasting and assessing the large-scale and long-term impacts of global environmental change on terrestrial ecosystems in the United States and China. In Real World Ecology: Large-scale and Long-term Case Studies and Methods, ed. S Miao, S Carstenn, M Nungesser, pp. 235-66. New York: Springer

Tsunogai S, Watanabe S, Sato T. 1999. Is there a "continental shelf pump" for the absorption of atmospheric $\mathrm{CO}_{2}$ ? Tellus B 51:701-12

Walsh JJ. 1988. On the Nature of Continental Shelves. New York: Academic. 520 pp.

Walsh JJ, Dieterle DA. 1994. $\mathrm{CO}_{2}$ cycling in the coastal ocean. I. A numerical analysis of the southeastern Bering Sea with applications to the Chukchi Sea and the northern Gulf of Mexico. Prog. Oceanogr. 34:33592

Walsh JJ, McRoy CP. 1986. Ecosystem analysis in the southeastern Bering Sea. Cont. Shelf Res. 5:259-88

Walsh JJ, Rowe GT, Iverson RL, McRoy CP. 1981. Biological export of shelf carbon is a neglected sink of the global $\mathrm{CO}_{2}$ cycle. Nature 291:196-201

Wang ZA, Cai W-J, Wang Y, Ji H. 2005. The southeastern continental shelf of the United States as an atmospheric $\mathrm{CO}_{2}$ source and an exporter of inorganic carbon to the ocean. Cont. Shelf Res. 25:1917-41

Wanninkhof R. 1992. Relationship between gas exchange and wind speed over the ocean. F. Geophys. Res. 97:7373-81

Ward BB, Devol AH, Rich JJ, Chang BX, Bulow SE, et al. 2009. Denitrification as the dominant nitrogen loss process in the Arabian Sea. Nature 461:78-81

Warner JC, Sherwood CR, Arango HG, Signell RC. 2005. Performance of four turbulence closure models implemented using a generic length scale method. Ocean Model. 8:81-113

Wilkin J. 2006. The summertime heat budget and circulation of southeast New England shelf waters. F. Phys. Oceanogr. 36:1997-2011

Wollast R, Mackenzie FT. 1989. Global biogeochemical cycles and climate. In Climate and Geo-Sciences, ed. A Berger, S Schneider, JC Duplessy, pp. 453-73. Dordrecht, Neth.: Kluwer 
k

Annual Review of

Marine Science

Volume 3, 2011

\section{Contents}

Geologist at Sea: Aspects of Ocean History Wolfgang $H$. Berger

Submarine Paleoseismology Based on Turbidite Records Chris Goldfinger

Natural Processes in Delta Restoration: Application to the Mississippi Delta Chris Paola, Robert R. Twilley, Douglas A. Edmonds, Wonsuck Kim, David Mobrig, Gary Parker, Enrica Viparelli, and Vaughan R. Voller

Modeling the Dynamics of Continental Shelf Carbon Eileen E. Hofmann, Bronwyn Cabill, Katja Fennel, Marjorie A.M. Friedrichs, Kimberly Hyde, Cindy Lee, Antonio Mannino, Raymond G. Najjar, fobn E. O'Reilly, Fobn Wilkin, and Fianbong Xue

Estuarine and Coastal Ocean Carbon Paradox: $\mathrm{CO}_{2}$ Sinks or Sites of Terrestrial Carbon Incineration? Wei-fun Cai

Emerging Topics in Marine Methane Biogeochemistry David L. Valentine

Observations of CFCs and $\mathrm{SF}_{6}$ as Ocean Tracers Rana A. Fine

Nitrogen Cycle of the Open Ocean: From Genes to Ecosystems Fonathan P. Zehr and Raphael M. Kudela

Marine Primary Production in Relation to Climate Variability and Change Francisco P. Chavez, Monique Messié, and 7. Timothy Pennington

Beyond the Calvin Cycle: Autotrophic Carbon Fixation in the Ocean Michael Hïgler and Stefan M. Sievert 261

Carbon Concentrating Mechanisms in Eukaryotic Marine Phytoplankton John R. Reinfelder 
Microbial Nitrogen Cycling Processes in Oxygen Minimum Zones Phyllis Lam and Marcel M.M. Kuypers

Microbial Metagenomics: Beyond the Genome Jack A. Gilbert and Christopher L. Dupont

Environmental Proteomics: Changes in the Proteome of Marine Organisms in Response to Environmental Stress, Pollutants, Infection, Symbiosis, and Development Lars Tomanek 373

Microbial Extracellular Enzymes and the Marine Carbon Cycle Carol Arnosti

Modeling Diverse Communities of Marine Microbes Michael 7. Follows and Stephanie Dutkiewicz.

Biofilms and Marine Invertebrate Larvae: What Bacteria Produce That Larvae Use to Choose Settlement Sites Michael G. Hadfield 453

DNA Barcoding of Marine Metazoa Ann Bucklin, Dirk Steinke, and Leocadio Blanco-Bercial 471

Local Adaptation in Marine Invertebrates Eric Sanford and Morgan W. Kelly 509

Use of Flow Cytometry to Measure Biogeochemical Rates and Processes in the Ocean Michael W. Lomas, Deborab A. Bronk, and Ger van den Engh 537

The Impact of Microbial Metabolism on Marine Dissolved Organic Matter Elizabeth B. Kujawinski 567

\section{Errata}

An online log of corrections to Annual Review of Marine Science articles may be found at http://marine.annualreviews.org/errata.shtml 